Historic, Archive Document

Do not assume content reflects current scientific knowledge, policies, or practices. 



\section{$I I B F A$}

IRECrot of

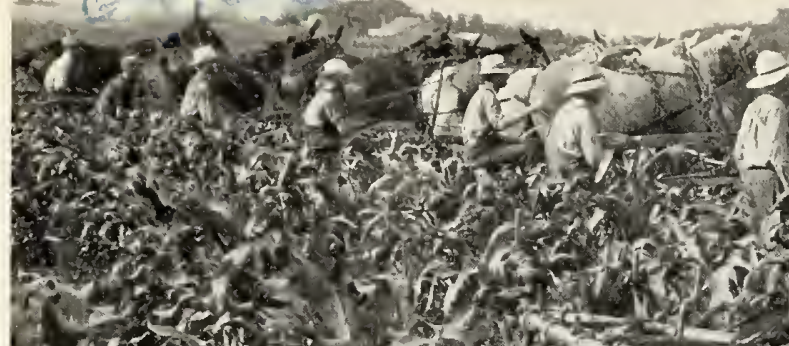

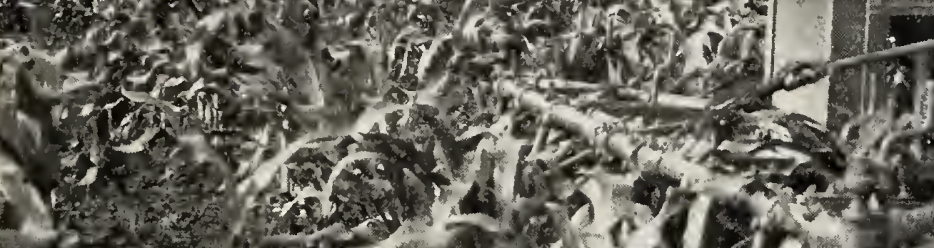

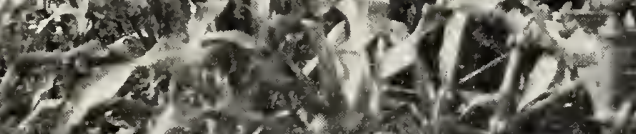

$\int$
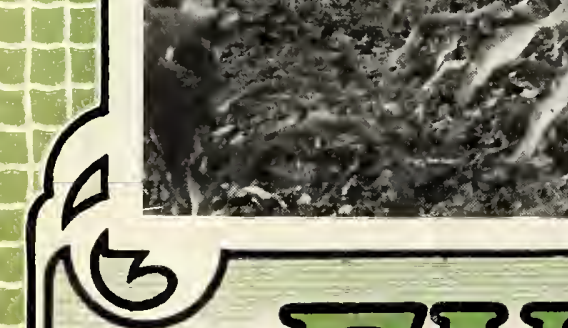

3

L
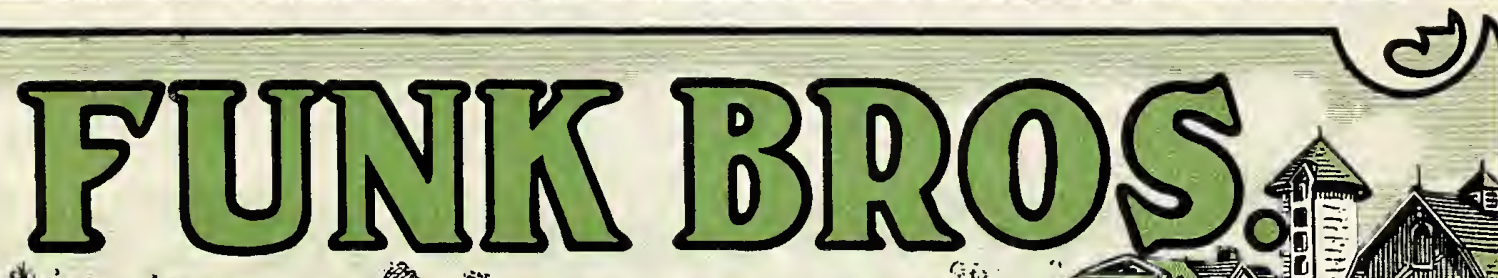

$\Delta$
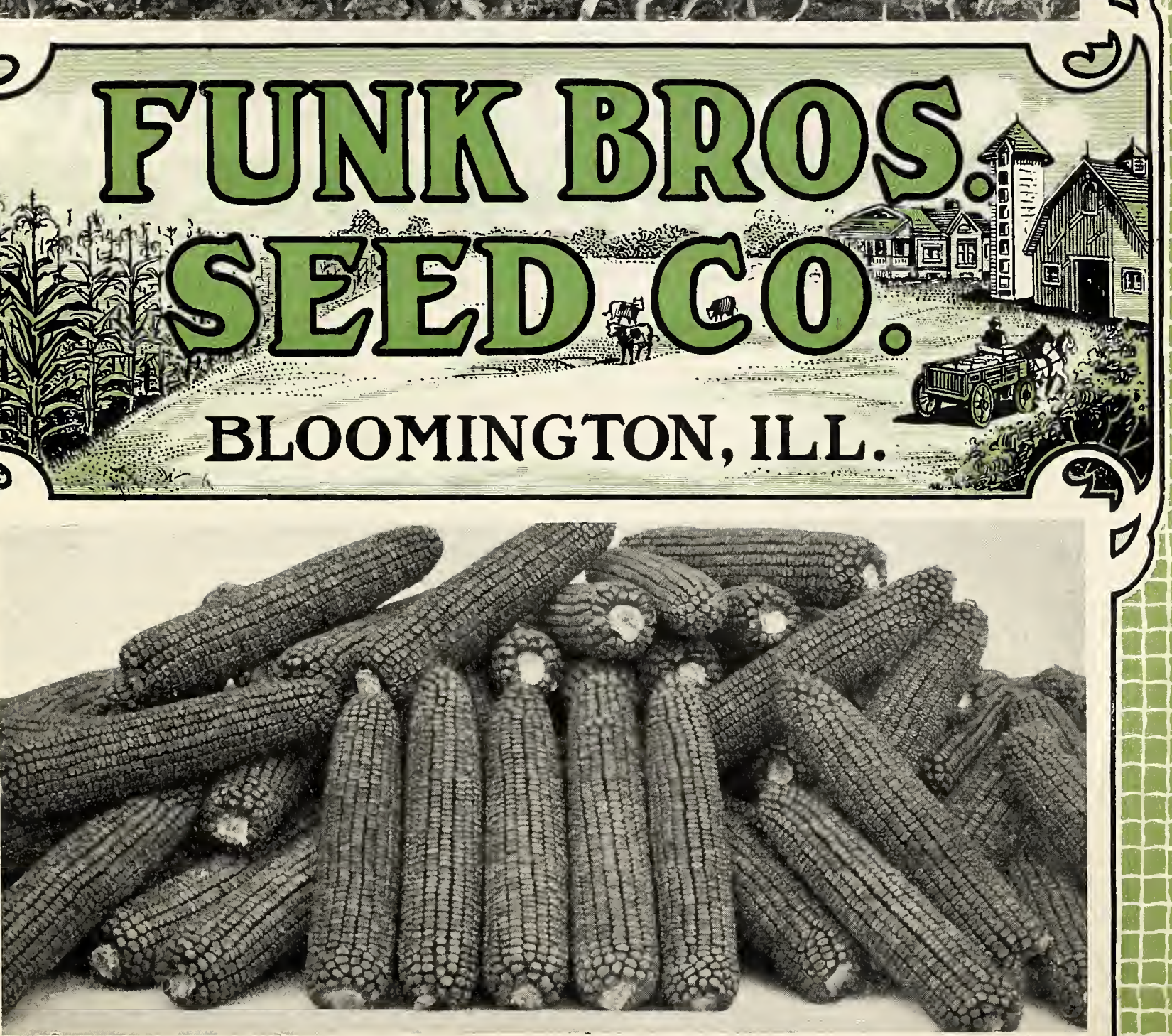

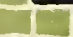
․․․ 


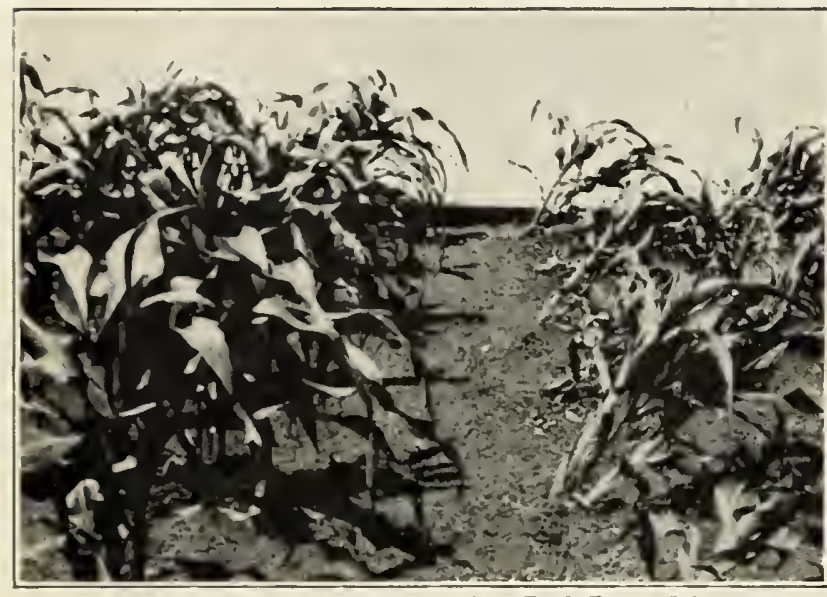

Photo Funk Farms July 1, 1928

Well Rooted Inbred

Weak Rooted Inbred

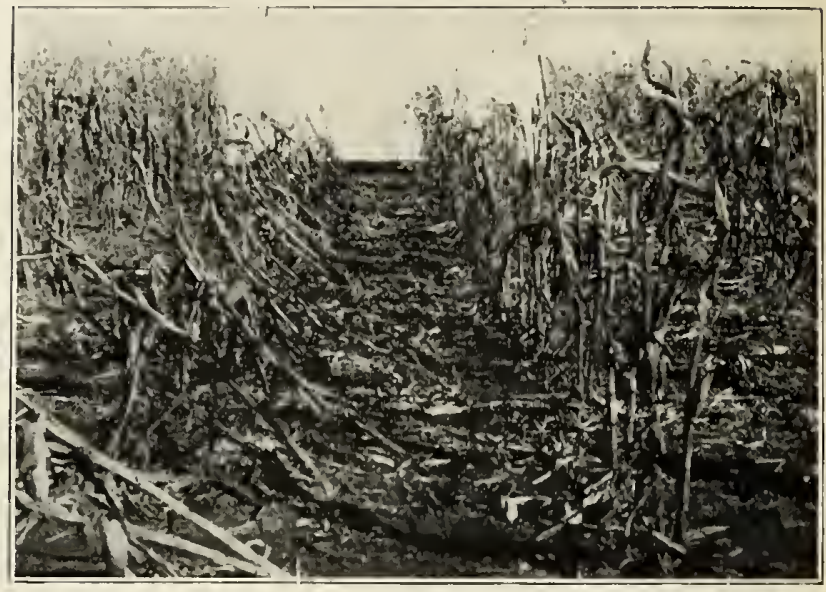

Photo Funk Farms Nov. 15, 1928

Weak Rooted Inbred

Well Rooted Inbred

\section{SCIENTIFIC CORN BREEDING}

Scientific work is only of seientific interest until it can be turned to some good use by man in making a more efficient world. Corn breeding is of minor importanee to the farmer until he ean utilize the results of it in corn production. We are now ready to give the farmer the benefit of our eorn breeding program in a larger way than ever before in the form of Hybrid Seed Corn. There is stored in our warehouse this year more Hybrid Seed Corn than was ever gathered together in one place before. No doubt it will be of interest to review bricfly the development of this Supcr Secd Corn.

In the spring of 1916 about 1500 ears of corn varying from the extremely rough to the extremely smooth type were planted in ear rows. This experiment was the beginning of the seleetion of the Utility Type Corn so popular at the present time. Two methods of breeding were practiced in this plot of eorn. In one ease, open-pollinated seed was seleeted from the better rows. In the other, the superior plants in the row were inbred. Inbreeding is the process of taking the pollen from the tassel of a plant, putting it on the silks of the same plant and at the same time exeluding all foreign pollen.

\section{Method of Breeding}

A small bag is secured over the small shoot before any silks appear. $\Lambda$ fter the silks are out and the tassel is produeing pollen, a larger bag is rlipped on the tassel in the evening. The next morning the tassel in this bag is shaken vigorously; the bag is removed and folded in half so as to retain the pollen; the small bag on the shoot is taken off and the open half of the pollen bag qniekly slipped over the shoot. Now the bag is straightened up and at the same time shaken vigorously in order to distribute the pollen over all of the sills. This bag is elipped in place and serves to protect the silks from foreign pollen, while at the same time it is large enough to accommodate the growing ear.

\section{Inbreeding Reveals Weaknesses}

The next spring, when this inbred seed is planted in ear rows, a large number of weaknesses show up, such as dwarf plants, plants with rolled leaves, individuals with weak roots and weak stalks, leaves of poor color or lacking in green material, plants which are smutted and plants having undesirable characters which are too numerous and eomplex to list here. Only the better rows are eonsidered for further work and only the superior individual plants of these better rows are again inbred. After several years of such selection and inbreeding uniform appearing types develop which are known as PURE LINES. Our Pure Lines represent the selection from thousands upon thousands of ear rows of inbred corn covering a period of 12 years. These Pure Iines are not suitable for the corn producer since they yield only about one-half as much as good open-pollinated varieties. 


\title{
No Corn
}

Is Better Than Its Roots

\begin{abstract}
These Roots are Characteristic of the weak rooted and well rooted Inbred Strains shown at the right. Root development is one of the factors influencing lodging in corn. Drought injury is closely correlated with the character of the root system.
\end{abstract}

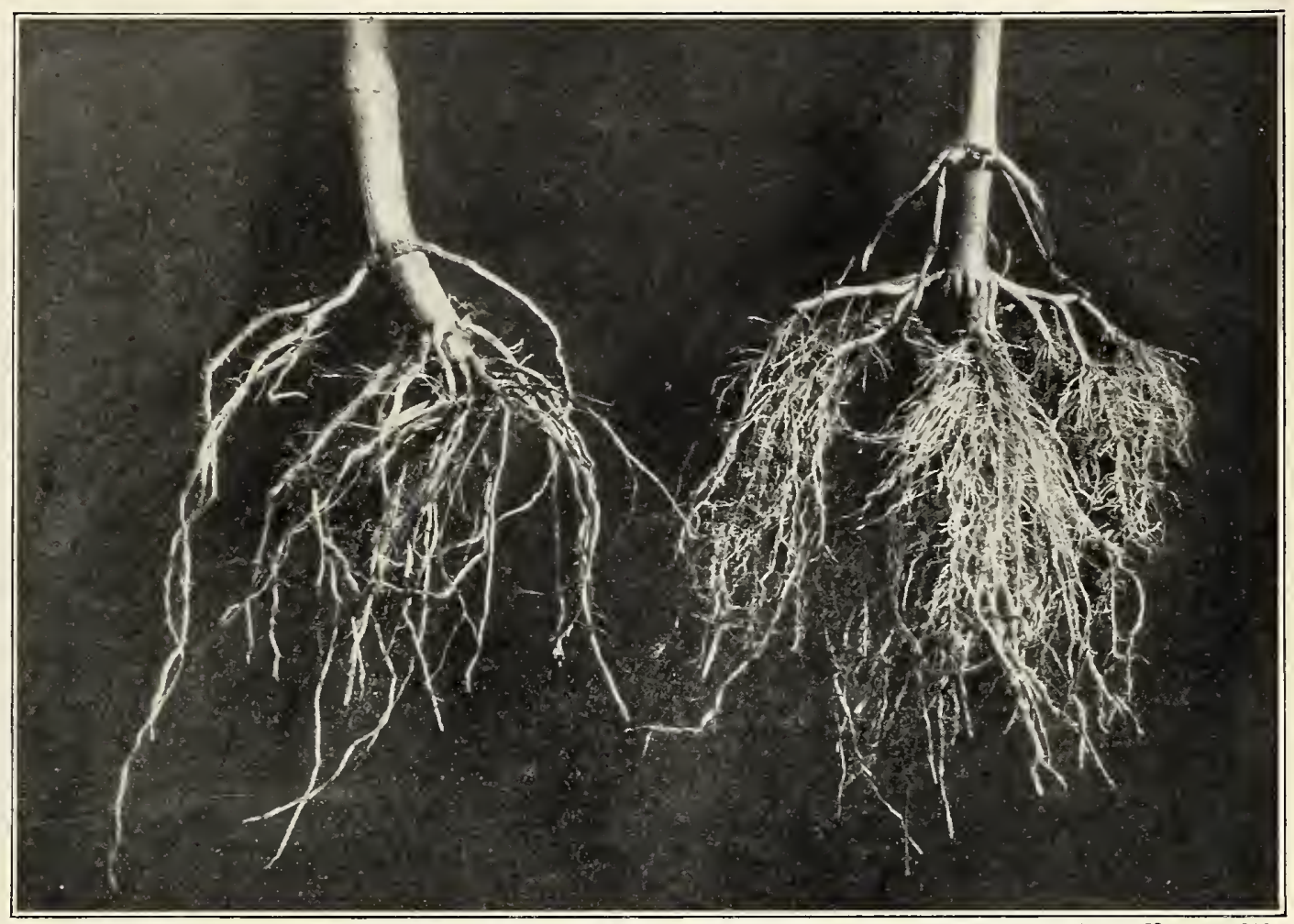

FUNK'S HYBRIDS ARE PRODUCED FROM WELL ROOTED INBRED STRAINS.

\section{Single Cross Seed}

When two of these Pure Lines are crossed, however, the yield lost on inbreeding is usually regained and the resulting Hybrids are extremely desirable from the standpoint of the producer. This crossing is carried out experimentally using the same methods practiced for inbreeding except that the pollen from one Pure Line is dusted on the silks of another Pure Line. A cross between two Pure Lines is known as a SINGLE CROSS. This kind of seed would probably be most satisfactory for the corn grower except for the fact that up to the present time it has been too expensive to produce in commercial quantities. Limiting factors in the economical production of Single Cross seed on a large scale are the low yield of the Pure Lines and the difficulties encountered in producing sufficient quantities of Pure Line Seed for large field plantings. Additional difficulties arise in that special planter plates are necessary for planting the small kernels from the Pure Lines which produce the vigorous, high yielding Single Cross Corn.

\section{Double Cross Seed}

The next best thing is to preduce DOUBLE CROSS SEED by the union of two different Single Crosses having no common Pure Line Parent. It was necessary to make thousands of single crosses before a few of sufficient merit were found for use in making Double Crosses. These were combined in every possible way and the ones which gave the best results for several years over a wide range of soil and climatic conditions were produced in larger quantities for commercial seed. Funk Bros. Seed Company has had Double Cross Seed available in somewhat limited quantities for a few years as Pure Line Double Cross No. 250.

\section{Production of Large Quantities of Seed}

In order to produce Single Cross Corn in large quantities detasselling methods were used. Two different Pure Lines were planted in a field in alternate rows. One of them was detasselled 


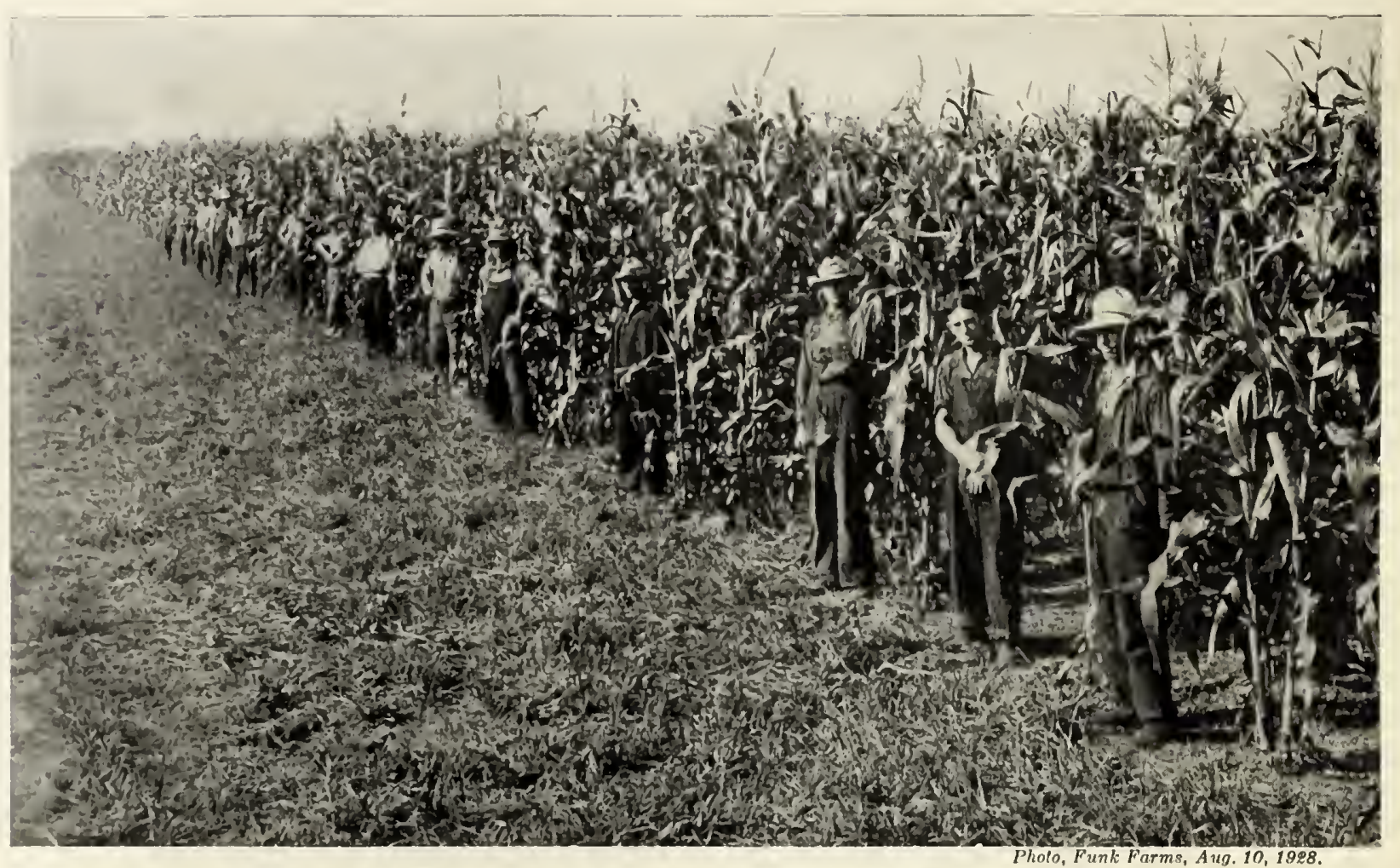

DETASSELING CORN TO MAKE HYBRID:SEED

Each field must be gone over five or six times. All the tassels are removed from the rows used for seed. Over a thousand dollars was spent detasseling corn this year.

throughout the ficld before any pollen had been produeed. This insured that the only pollen present in this isolated plot of ground eame from one Pure Line. The Single Cross seed is produced on the detasselled lows. This method produces seed on only one half the land. We have varied this method lately in order to secure seed from two-thirds of the land by planting two rows of one inbred together for detasselling and having every third row throughout the field for pollen produeers. This variation gives cqually good pollination and makes for more economical seed production.

\section{Producing the Double Cross Seed}

Double Cross sced is produced by planting two Sing] Crosses having no common Pure Line parent in a larger plot of ground for detasselling. Two rows of one Single Cross are detasselled throughout the field while every third row of the other Single Cross is left as a pollen producer. Double Cross Seed is ricked from the detasselled Single Cross rows and it is in this Double Cross that we are able to give the producer the benefit of years of breeding and careful plant and seed selection.

\section{Quality Corn}

Ifigh yield has not been the only consideration in this Coln Breeding Program. If yield had been the sole objective the problem would have been greatly simplified. It has been our demand at all times that the seed turned to the farmer produce a desirable type plant as previously deseribed and a good ear of high quality corn. This means that it must mature early and that it must be more resistant to ear rots than the open-pollinated varieties usually grown. These standards have ruled out some exeeptionally high yielding hybrids. What would it profit a man to have a big yicld if it was all on the ground or of such poor quality that it would not grade at the elevator? We have long worked on the principle that there comes a time when quality is more important than yield. 


\title{
Some Hybrids Are More Desirable Than Others
}

\author{
Tall Hybrids - - Short Hybrids \\ High Ears - - - Low Ears \\ Total Corn from 25 Hills \\ 30 Lbs. - - - $\quad 28$ Lbs. \\ Sound Corn \\ 10 Lbs. - - - $\quad 26$ Lbs. \\ Contests, newspaper publicity and exploi- \\ tation have built up a "Tall Corn" myth. \\ It is kept alive by song and by the popular \\ fancy of the bystander. Tall Corn is not \\ necessarily high yielding corn. For commer- \\ cial purposes we believe in the shorter, low \\ eared, well rooted, stiff stalked Hybrids which \\ produce a good yield of high quality corn.
}

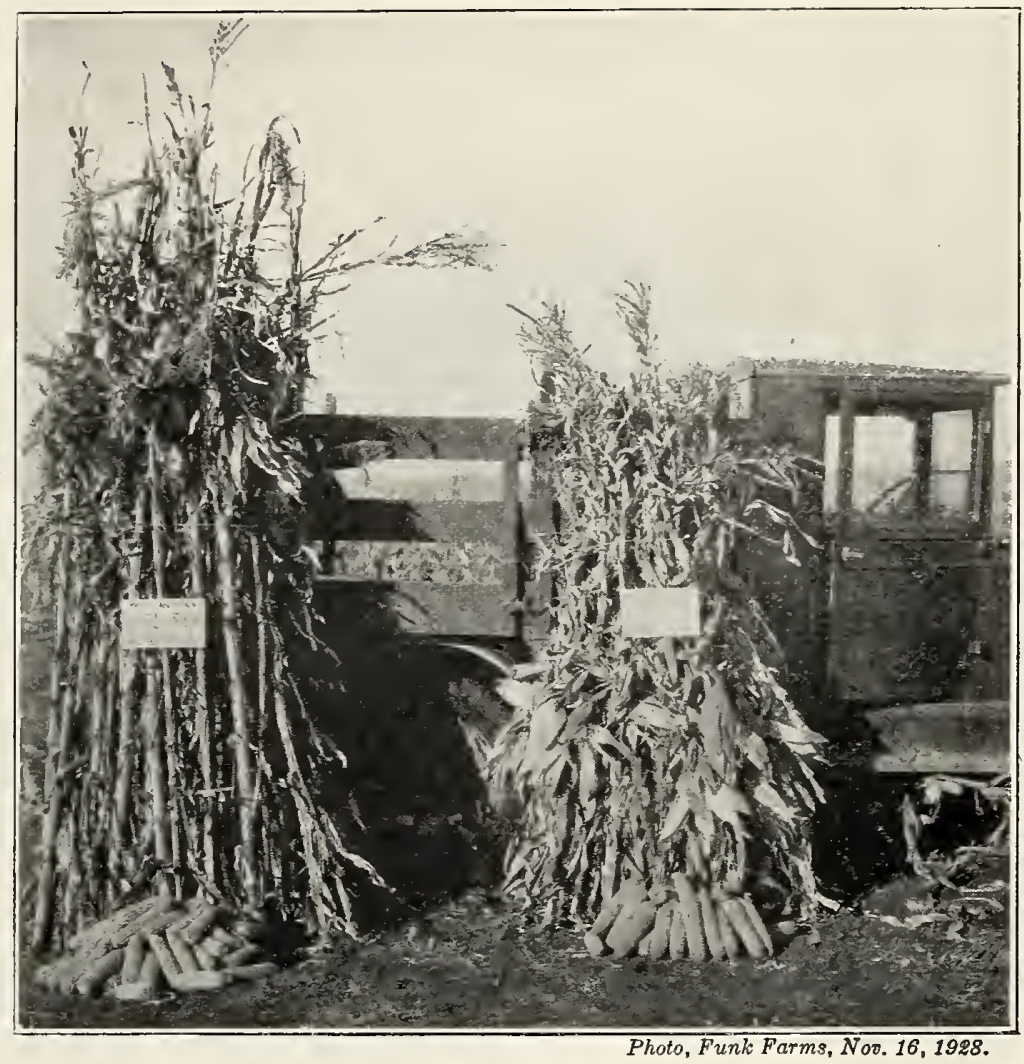

\section{Pure Line Double Cross No. 250}

The reports from this cross have been very pleasing. Pure Line Double Cross No. 250 was distributed in considerable quantity last year and over a wide area. It was grown by farmers on large acreages and found to be good. If all of the reports had been 100 per cent favorable we would have been more than surprised for no corn has yet been developed which is adapted to all conditions. With varying latitude and soil it is necessary to have varieties of corn capable of producing best results under a given set of conditions. Pure Line Double Cross No. 250 is a little too early to please the producers of some localities. To these we recommend the later maturing Hybrid No. 365, for there is no doubt as to the superiority of Pure Line Double Cross No. 250 under conditions where Hybrid No. 365 is too late.

Pure Line Double Cross No. 250 bears a good ear at a convenient height on a short sturdy stalk.
We have never marketed seed which produces such a high rield in proportion to the amount of stalk. Nutrients from the soil are necessary to produce grain so in the interests of economy of plant food WHY grow a larger proportion of stalk? Efficiency is the keynote of economy and lowered cost of production in industry. Corn Growers should not fail to take this opportunity to put Corn Production on a more efficient basis.

Our entire supply of Pure Line Double Cross No. 250 seed was harvested early. It was dried rapidly on our drying racks. This method is productive of highest quality seed. After drying each ear is carefully examined and only the best ears are retained. Then they are tested, shelled, graded, and treated with Improved Semesan $\mathrm{Jr}$. As stated before, from the standpoint of seed corn, we have spared no pains to turn out a high quality product. which is a big step toward a good crop. 


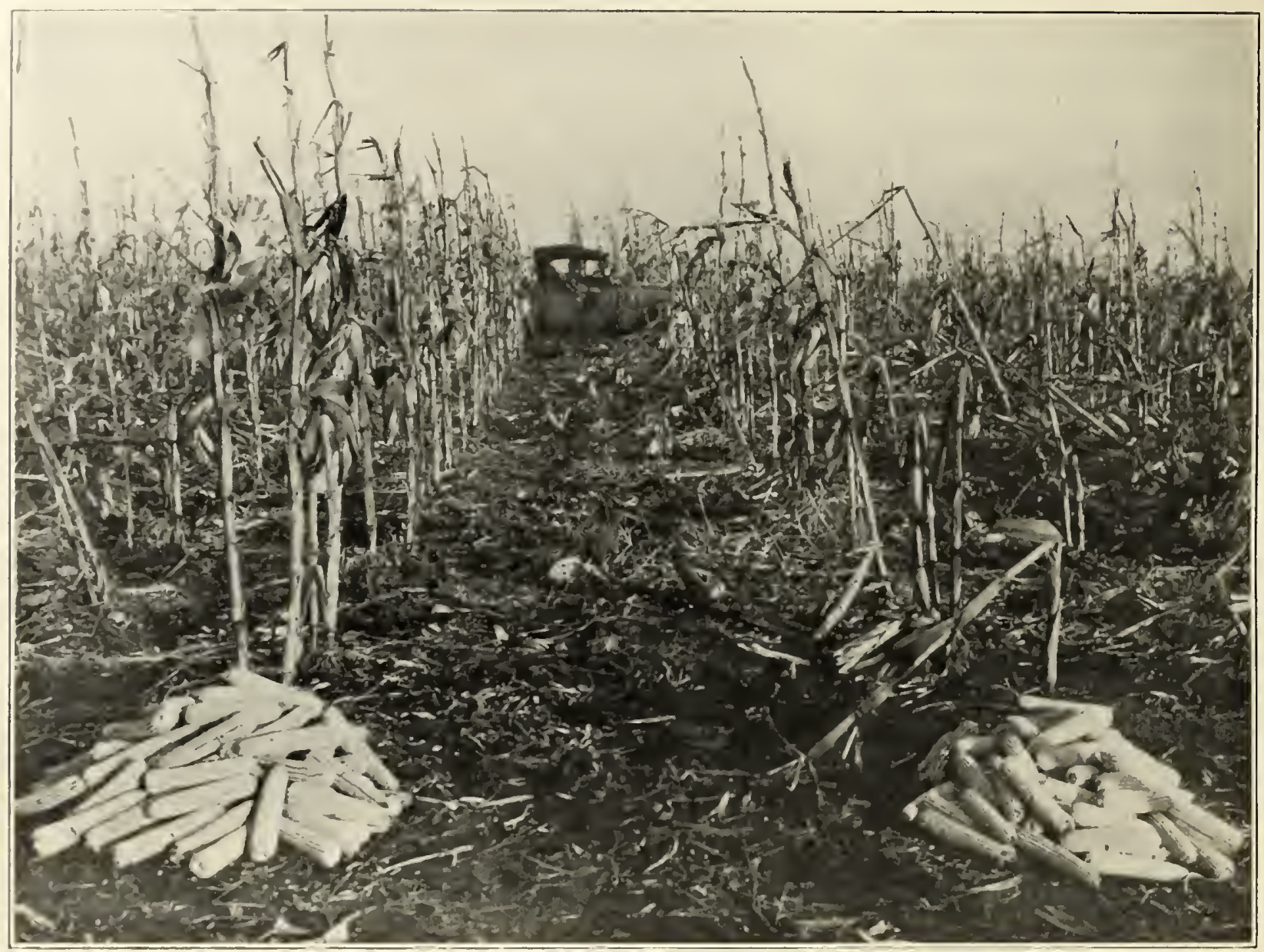

HYBRID NO. 365

Row 7068 bu. per acre
One of the better Planter Box Samples Row $7255 \mathrm{bu}$. per acre

Hybrid No. 365 was superior in every respect to the 112 Planter Box Samples.

\section{Hybrid No. 365}

Never before have we introduecd a new strain of coln witl the fceling of eonfidence which aecompanies the offering of Hylsrid No. 365. Singlc Cross No. 365 is the female parent of this Hybrid. Inother high yielding strain was used as the pollen frarent. Sturdy, low growing and vigorous, this Hybrid is further confirmation of the faet that high vield can be olstained without TALT, S'TAIKS. Hybrid coln will, no doubt, soon reli. gatc the "Tall Corn" myth to its proper status among the Nursery Rliymes. Why reach up after such a high pereentage of the cars in the Fall, or stonp to jick them from a down stalk when Hybrid 365 offors you its ear at a convenient height (yard stick high). The stiff sturdy stalk and strong root system reduces the hazard of down eor'il.

Hybrid 365 matures in approximately 115 days. We advise early planting and in this case more especially urge it for Hybrid No. 365 survives the cool nights of late spring and early fall much better than any we have cver offered beforc.

Our supply of seed was harvested early and dried properly. Before it comes to you it is carefully selected, tested, shclled, graded and, as a further insurance, it is treated with Improved Semesan Jr. Never has such eare and selection been put into seed corn in order to insurc a good crop of high quality corn. Our supply has never equalled the demand. Order early. 


\section{HYBRID No. 365 VS. FARMERS' Corn}

In one of our experimental plots this year we grew 112 samples of corn taken from Farmers' Planter Boxes in the field at the planting time. Each sample was planted untreated and treated with Improved Semesan Jr. but this phase will be reported later, on the page devoted to Seed Treatment. Hybrid No. 365 was planted in this plot as a check on soil uniformity. The average yield of Farmers' corn untreated was 48.8 bushels per acre. Hybrid No. 365 yielded 66.6 bushels per acre. When it is remembered that the 112 Farmers' Samples were collected from the heart of the Corn Belt within a 75 -mile radius of Bloomington there can be no doubt as to the superiority of Hybrid No. 365. Planted early Hybrid No. 365 has yielded from 15 to 25 bushels per acre more than it did in this plot which was planted late. Hybrid No. 365 is truly a super corn.

\section{Sound Corn}

Late planting such as was necessary in this experiment, due to the delay in collecting the 112 Farmers' Samples (May 25, 1928) is not conducive to high quality corn. The Farmers' Samples averaged 71 per cent sound corn and the Hybrid No. 365 averaged 83 per cent sound corn. On the sound corn basis the average yield of the Farmers' Samples and Hybrid No. 365 are 36.1 and 54.3 bushels per acre respectively.

\section{Funk's 90 Day}

Funk's 90 Day is an Early Yellow Dent Variety originated by Mr. E. D. Funk in 1893. It is no easy matter to maintain such an early corn where the growing season approximates 120 days. Constant attention and selection are necessary. We are ever applying the most advanced methods of corn breeding in the production of this seed. You obtain the benefit of many years of scientific breeding and selection when purchasing Funk's 90 Day corn. It is unsurpassed for those who desire an early maturing corn which combines profitable yield with unusual feeding value.

Funk's 90 Day possesses the stiff stalk and vigorous root system which are so necessary to good yield. It stands up unusually well. The ears are from 7-9 inches long 6-7 inches in circumference and have from 16-18 rows of kernels. The grain is of a bright golden color, deep, oily, and of high quality. The percentage of rotten ears is remarkably low. A small cob permits the early drying out to proceed rapidly.

Its resistance to cold in the spring makes Funk's 90 Day a very desirable variety for early planting. For growers who want an early maturing, high yielding corn to hog-down this variety is excellent. Funk's 90 Day, planted early, matures for feeding purposes by the first of September.

The quality of our seed is excellent. It germinates well, produces strong, healthy, vigorous seedlings which are important steps in securing a good crop. No mistake could be made in purchasing such a high quality product.

\section{Will County Favorite}

To Mr. Wm. Webb, Plainfield, Illinois, belongs the credit of originating Will County Favorite. Beginning in $1900 \mathrm{Mr}$. Webb combined Golden Yellow, an early variety of corn that he had been working on since 1885 with Western Plowman and Edman's.

Western Plowman at that time was a large late yellow corn with a broad kernel but a good yielder and Edman's corn was a yellow variety, medium early, with a rather small, deep kernel. Mr. Webb spent a good deal of time in producing the present Will County Favorite to conform to the type that he considered best to meet a standard which would be especially adapted to the Northern third or half of Illinois. Will County Favorite has matured in splendid shape for us in a little less than 100 days and the product this year shows exceptional resistance to disease. It conforms to the Utility Type and has been a consistent high yielder and also prize winner in this and other states.

In 1924 Will County Favorite was certified and registered by the Illinois Crop Improvement Association, Mr. William Webb as originator and grower. 


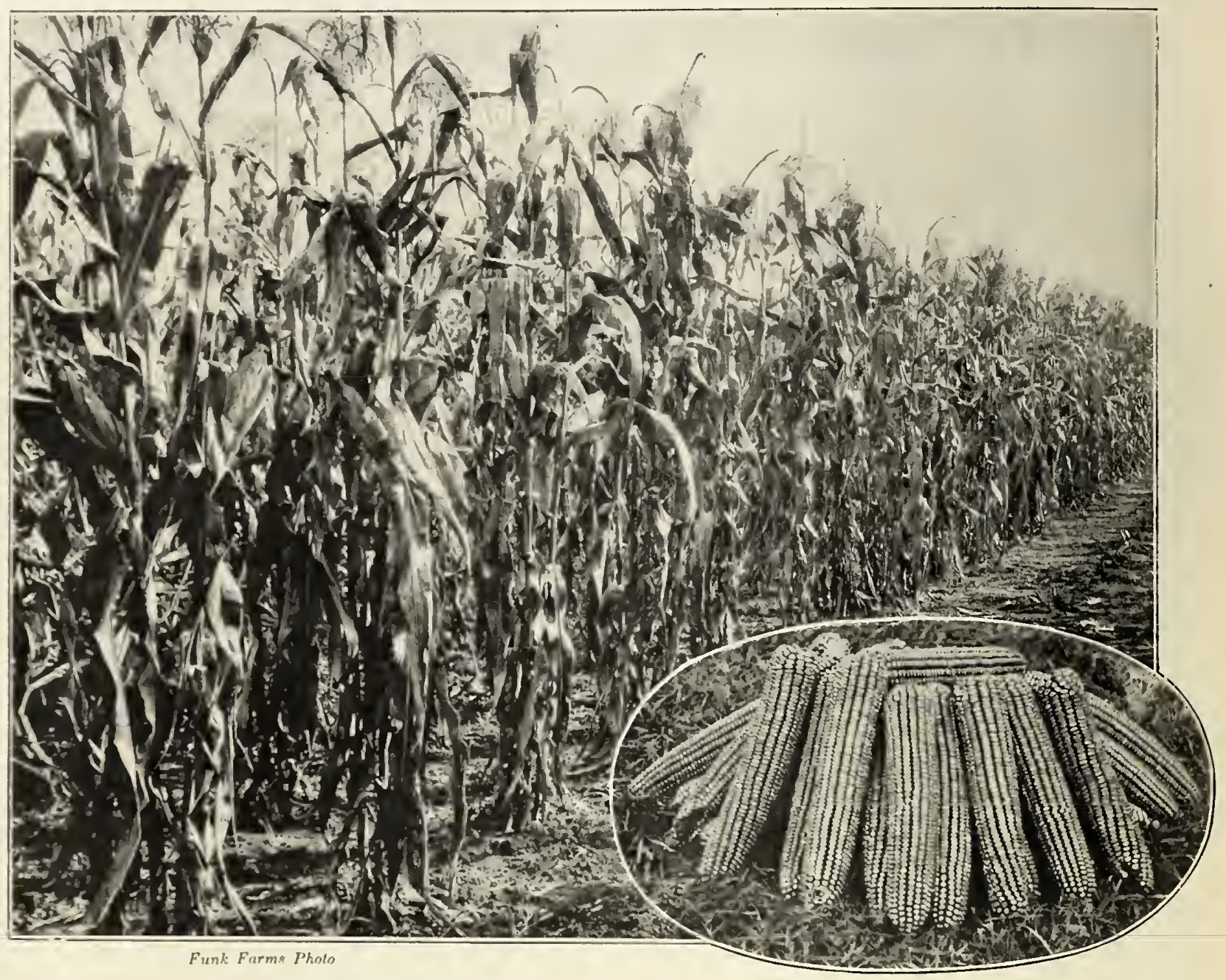

\section{Funk's Ye110w Dent, Strain 176 A}

This is the Original ['tility Type Corn. The original strain of Yollow Dent olutaiume from Mr. J. I. Reid Jy F. D. Funk in 1902 laas grour through many changes; the Ctility Type rating from 1916.

Funk's lellow Inent, Sitrain $176 \mathrm{~A}$ has proven its superi. ority to the older rough trive corn. There is 110 romparison when quality und test wright arr considrred. This Utility Type corm has jrowen to lue more resistunt to corm diseases and to ear rots than its rougluer, starehier predecessor. Serd from the same finn rars used in initinting the corn hreeding program formml the foundation stock for this suferior strain of open-jollinated corm.

The light eoldon rolor and rich lustre of this corn is sure to plrase you. The uniformity of ear amd stalk are exerptional in an ofen-follinater variety. The ars are S-11 inches long. i.s inches in rireumforenec aud shell out 85 to 90 jer ront of hravy high quality eorn.
Funk's Yollow Dent. Strain 176 A matures perfectly in approximately 120 days. It lends itself well to early Jlanting. The stalks are vigorous and sturdy and rango from 8-12 foet in height. The stalks are well anchored by a well-developed root sustem. Such characteristies mean that this corn will not break over or blow over under conditions other varieties would. Funk's Yellow Dent, Strain $176 \mathrm{~A}$ hats a greater resistance to lodging and stalk breaking thatn any open-pollinated variety we know of and there is probally a greater acreage of this corn planted in the Corn Belt than any other stıain of Yellow Dent Corn.

Our seerl is of excellent quality and was all produced from seerl tested for Vigor and Freedom from Disease. This Strain $176 \mathrm{~A}$ is the best open pollinated corn we know of anywhere and in localities where it will mature we have no doulst as to its proving satisfactory. 


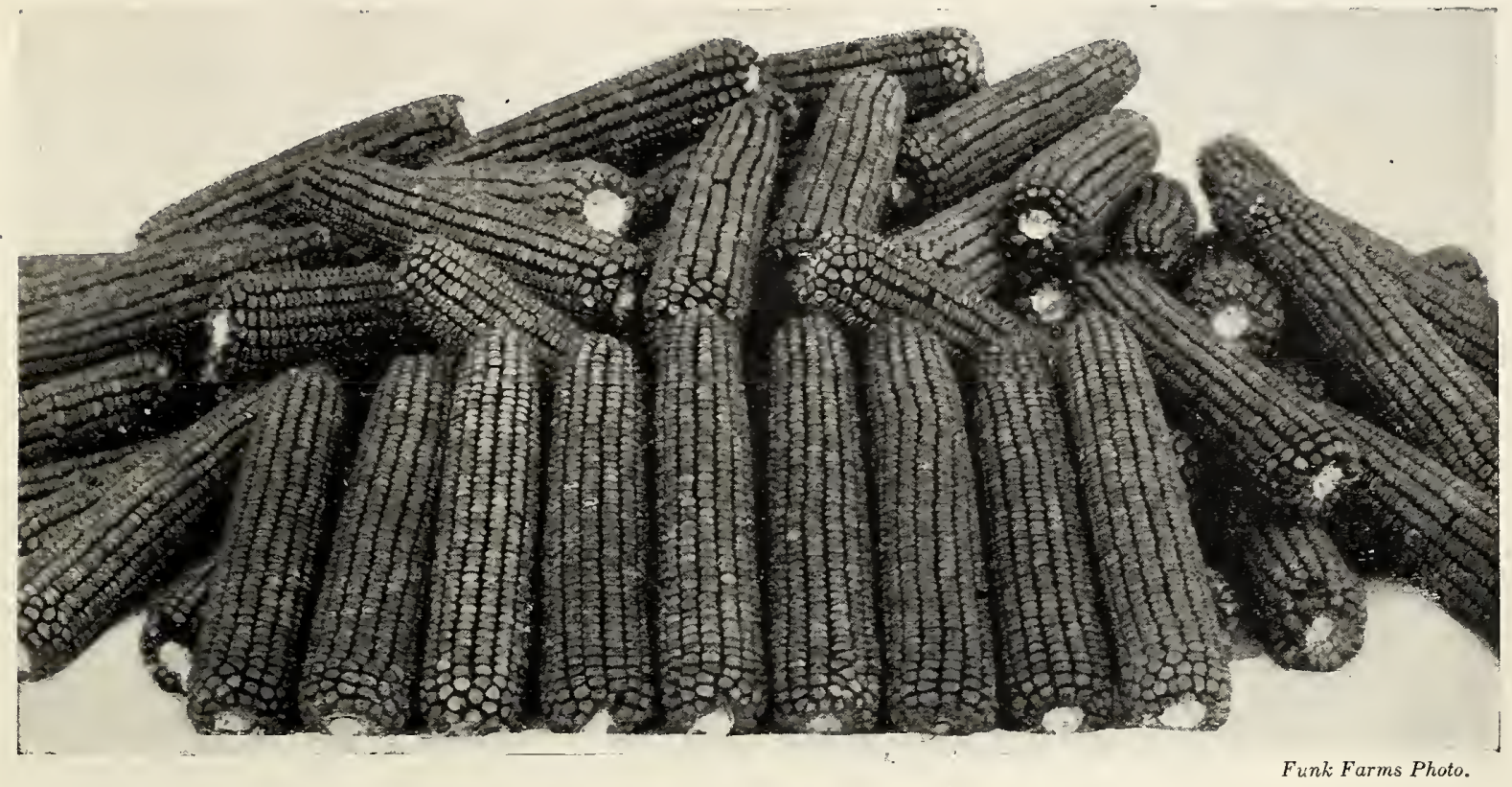

\section{Funk's No. 329}

Funk's 329 Yellow Dent is an open-pollinated corn maturing in approximately 100 days. Having been developed by selection from Funk's 90 Day it has retained many desirable characters of the earlier variety including a deep oily kernel with a small cob. This variety produces a larger ear than the 90 Day but is not so large as the later maturing 176 A Strain of Funk's Yellow Dent.

Funk's 329 has proven popular as a feeding corn. There is indeed much satisfaction in feeding ears of rich lustrous yellow color which are sound and hard. One bushel of this corn well-matured is the equal of two bushels of some later variety which is soggy and starchy even though the ears may be larger. A feeder is never pleased with chaffy corn.

The strong root system of Funk's 329 carries a stiff, vigorous stalk both of which are so vital to standing ability in corn. Farmers desiring a start of a high yielding, early variety will find that Funk's 329 fits their needs. It has yielded approximately 70 bushels per acre of sound, well-matured corn on the Funk Farms for several years. This seed was gathered early, stored in a dry warehouse where the temperature is never below $40^{\circ}$ and is now offered for your consideration.

\section{Our Experience In Corn Production}

Experiments by State and Federal agencies over a period of years has indicated that corn planted May 5 or before yields, on the average, 15 bushels per acre more than corn planted after May 25 . In general the loss is one bushel per day each day after May 5. This checks with our actual experience of many years of corn growing.

It has been observed that to obtain the best results from GOOD SEED, and especially from HYBRID SEED, that:

1. It should be planted early.

2. It should not be planted thicker than the fertility of the land warrants.

3. It should be cultivated sufficiently to check weed growth.

4. Shallow cultivation destroys the weeds. 


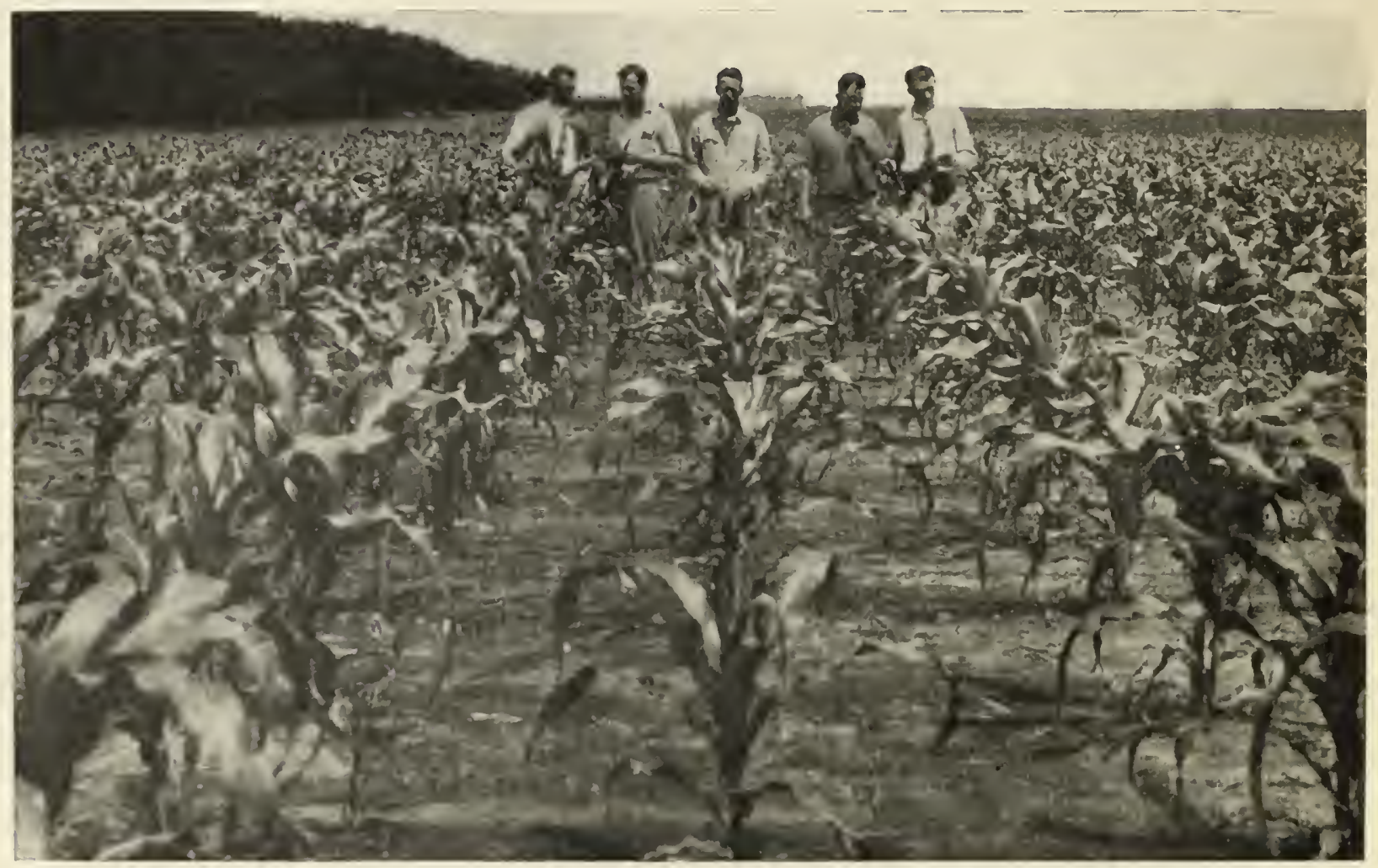

Photo Funk Farms, July $\$, 1928$

SEED TREATMENT IMPROVES VIGOR, STAND AND UNIFORMITY

Row on Left-

Disease Free Seed Treated
Middle RowOrdinary Seed Untreated
Row on Right-

Ordinary Seed Treated with Improved Semesan, Jr.

\section{Improved Semesan Jr.}

\section{Use Dust Treatment on Your Corn}

One more year's work with seed disinfectants has strengthened our belicf that Improved Semesan . $r$. is the luest arailable at the present time. Improved Semesan .Jr. has again proven to be the safest, cheapest, and most effective. Best results are obtained when it is used with good seed. No seed treatment could be expeeted to inerease the vitality of poor, low germinating seed corn.

Last year, at corn planting time, our salesmen collected 112 samples of eorn from Farmers' Planter Boxes. Among other things, we wanted to know how seed treatment would benefit Farmers' eorn. In order to study this effect, one row of each sample was planter as it eame from the planter box. Another row was planted from the same sample treated with Improved Semesan Jr.

\section{Improved Semesan Jr. Benefits Farmers' Corn}

Of the 112 Farmers' Samples, 22 yielded more than 55 bushels per aere untreated while treated with Improved Semesan Jr. 43 of them yielded more than 55 bushels per aere. Only three of the samples yielded less than 25 bushels per aere and the same three samples treated yielded less than 25 bushels per acre. These three samples were of such poor germination that the owners probably had to replant their corn. No seer treatment compound could be expeeted to benefit sueh poor seed eorn. Nine of the Farmers' Samples yielded between 25 and 40 bushels per aere untreated and the yicld of all but two of them was inereased to over 40 bushels per acre when treated. The majority of the Farmer's' Samples, 78 in all, yielded between 40 and 55 
bushels per acre untreated. The average untreated yield of these 78 samples was 48.5 bushels per acre. Treated with Improved Semesan Jr. the average yield of these same 78 samples was 52.0 bushels per acre. The increase of 3.5 bushels per acre for treatment cost approximately $2 \frac{1}{2}$ cents per acre. A farmer with 100 acres of corn would have been 350 bushels ahead by treating his corn with Improved Semesan Jr. and this increase would have cost but $\$ 2.50$. It is obvious that these farmers of Central Illinois would have profited greatly by using seed treatment.

\section{Improved Semesan Jr. Best on Good Seed}

The use of dust treatment on seed corn has been found to fit in with other good farm practices. The most consistent increases have been obtained by using Improved Semesan Jr. on GOOD SEED while on chaffy, starchy or low germinating seed no increases have been obtained. Experiments carried out this year at a number of different places in Illinois using several kinds of corn which was selected and tested by different men bring out the importance of treating all of the corn planted.
Briefly, the increase for treating well selected seed was between four and five bushels per acre. Testing gave an increase of about three and onehalf bushels per acre while both testing and treating gave an increase of approximately six bushels per acre. These figures indicate that testing or treating good seed result in about the same returns. When the seed was both tested and treated the greatest increases were obtained. Similar results could not be expected unless well selected, viable seed from a good strain of corn was used.

These experiments have demonstrated to us the very decided benefit to be gained by the Farmer from the use of Improved Semesan Jr. With the exception of a few experimental plots all of the corn planted on the Funk Farms is treated. Even corn which is tested for Vigor and Freedom from Disease is treated. This does not mean that we think seed treatment can take the place of testing but that it is merely another means by which a Farmer can improve his seed corn at a low cost. Treating seed corn with Improved Semesan Jr. is a good insurance against certain diseases, especially when unfavorable spring conditions prevail.

\section{Ceresan for Small Grain \\ A Dust Treatment for Oats Smut}

Dr. Benjamin Koehler, Plant Pathologist of the Department of Agronomy. University of Illinois, makes the following statements regarding Ceresan in the Extension Messenger of the Agricultural Experiment Station, under date of November 7, 1928.

"A dust treatment for seed oats which promises to be considerably superior to the standard formaldehyde method of oats disease control during the past 30 years has been found after four years of research. Discovery of the new method comes as the latest scientific development in the more efficient production of a crop which this year was grown on approximately 4,100,000 acres of Illinois farm land."

"Added yields nearly twice as great as those from the standard formaldehyde treatment have been obtained with the dust treatment. The dust is an ethyl-mercury-chloride compound. The superior yields from the dust treatment are attributed to the fact that the new compound not only gave perfect smut control but also checked other diseases which beset the oat plant, such as seedling dispases caused by infection from the soil.",

"Seed oats can be treated with the new dust method for a cost of only about 10 cents a bushel for materials. The compound is being manufactured by one of the commercial organizations under the trade name of CERESAN. In the experiments three ounces of the dust were used

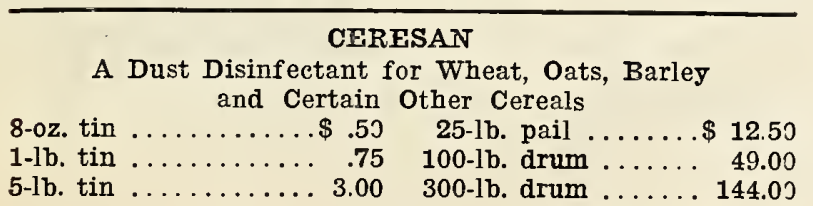

on each bushel of grain. As in the case of all dust treatments, thorough mixing of the dust with the grain in a good homemade barrel-type mixer or commercial mixer is necessary."

"Chemical treatments for the protection of seeds of farm crops against disease long have attracted the interest of scientists, because such treatments are more convenient and fool proof than liquid treatments. Previous to the conclusion of these experiments, successful dust treatments had been available for wheat and corn, but these same treatments had failed as a remedy for oats smut."

"It has only been within the past two seasons that the ethyl-mereury-chloride compound was found. In one experiment comprising ten replications with 60 Day oats, the yield under the new dust treatment was increased an average of 14.2 bushels an acre over what it was without treatment. In another experiment involving ten replications with Big Four oats there was an average increase of 19.1 bushels an acre."

SEMESAN Jr.

A Dust Disinfectant for Seed Corn

4-oz. tin .........\$.5) 25-lb. pail .....\$31.25

$1-l b$. tin . . . . . . $1.75 \quad 100-1 b$. drum . . . . 120.00

5-lb. tin . . . . . $8.00 \quad 300-1 b$. drum ..... 345.00 


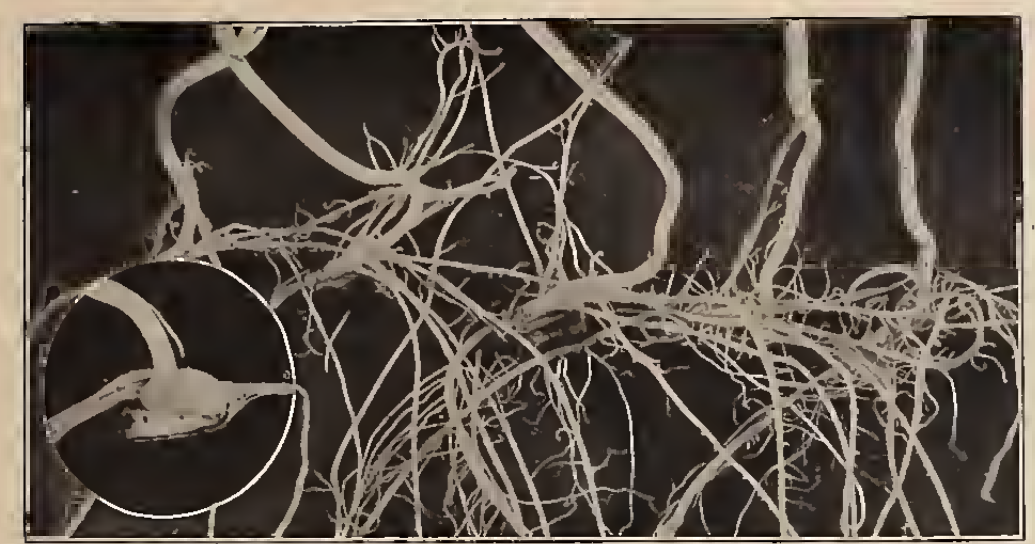

Strong:Sprouts_-Weak Sprouts

Plenty of Roots Few Roots No Disease-_ Disease Good Seed-Poor Seed A Good Crop A Poor Crop

Profit Loss

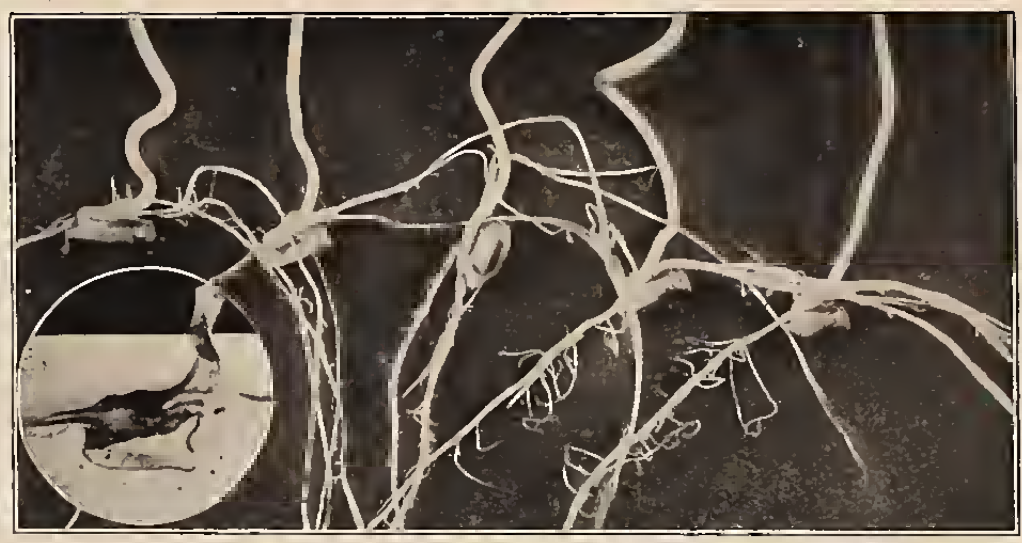

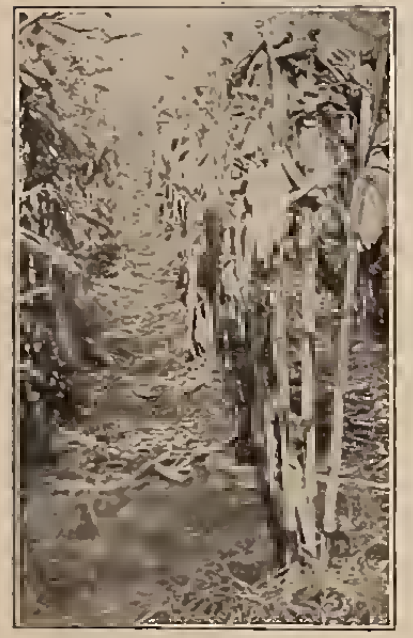

GOOD SEED

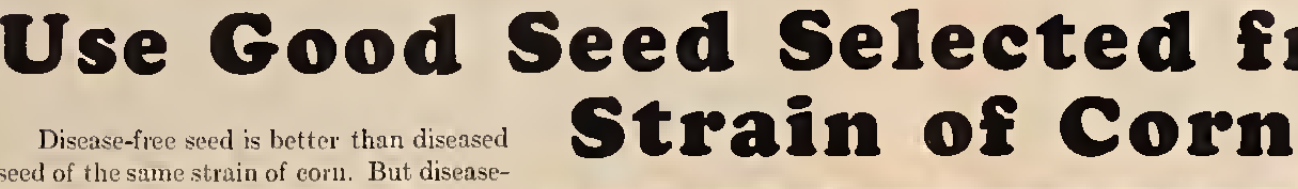
ree seed of a poorly bred and poorly selected strain may still be very inferior seed breanse it will produce a crop that may fall down, break over, and rot in the field. The seed may have been viable, vigorous in gerrunation, and even free from disease, but

COMPARE the cost per acre of your Seed Corn with your per acre cost for Seed Wheat, Clover, Alfalfa, Oats, etc. High Grade Seed Corn

Costs Less Per Acre Than Seed for Other Crops.

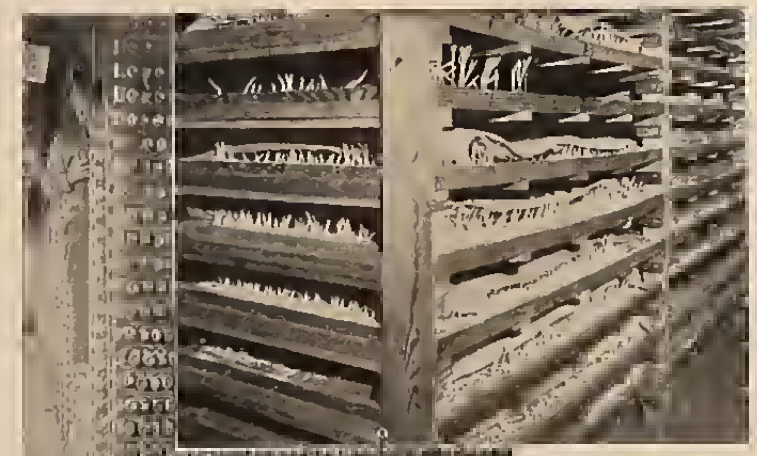
their roots deep into the soil, to produce strong stalk, and to mature a high yield of sound corn. Poor seed is too expensive to plant. No one that expects to keep out of the "nurginal" elass can afford to use poor seed corn.

LET US TEST YOUR SEED Funk's Par-Post

Disease Free Seed Corn Testing Service SIMPLE AS A. B. C

Two eents per ear. You send the corn to us in envelopes which f. 7 rom G.

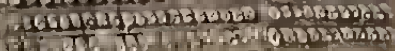

chunce for mix up. Corn is our greatest cash crop. Disease cuts yield $10 \%$ to $50 \%$

It has taken years of hard work, study and experience to qualify ourselves to serve farmers. See us, write or phone for special instructions.

Send me Funk's Par.Post Testing Information and.. Envelopes.

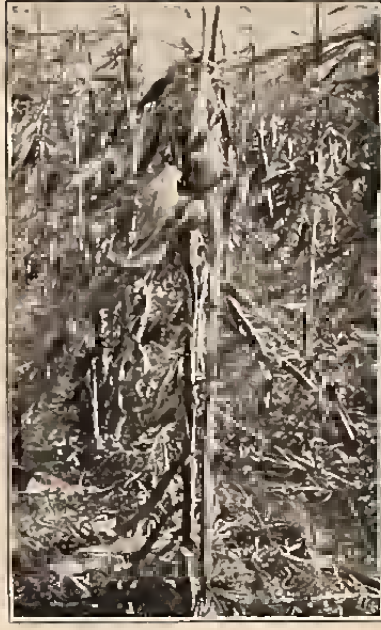

POOR SEED 


\section{SILVERMINE}

Funk's Silvermine is a medium early maturing strain of Iowa Silverminc. It has a good sized stalk, stands up well and makes a better yield on thin land than some of the later maturing, ranker growing varictics. The ears are cylindrical, of medium circumference, and from 9-10 inches long. The bright, creamy white kernels are decp and broad. Funk's Silvermine is adapted to a wide range of soil and climatic conditions and is onc of our more popular white varieties.

\section{KR U G CORN}

Krug Corn was discovered a few years ago in Woodford County which adjoins our own county of MeLean on the north.

Krug Corn is the result of many years of careful selection and combined with germination tests, eliminating the discased ears.

This corn has given such a good account of itsclf under a wide range of conditions and has been so well advertiscd that it is hardly necessary to go in to further details.

The seed we are offering conforms to the truc Krug type-was produced from discase frec sced and the quality is extra good.

\section{BLOODY BUTCHER}

Bloody Butcher is a whitc-capped red corn which matures in approximately 90 days. Our experience shows that it can be grown successfully anywherc in the Corn Belt.

Bloody Buteher has been grown for a long time on the Funk Farms in fields we expected to "hog down"-and gives splendid satisfaction. If you want an carly corn to "log down," Bloody Butcher will fill the bill exactly. Under average conditions we turn our hogs in on this corn about the 15 th or 20th of August.

\section{BOONE COUNTY WHITE}

Boone County Whitc lias a great record and many customers come baek year after year for this varicty. We figure about 120 days of average growing weather is required to earry this corn beyond the danger line of frost. We do not recommend farmers to grow this variety execpt under conditions where it is known to mature properly.
GOLD STANDARD LEAMING

Funk's Gold Standard Leaming is distinctly a silage and feeding corn. The ears are medium to large in size and have a rieh golden color which is characteristic of this variety. It is the favorite of fecders and matures in 120 days.

\section{BARLEY}

As a money crop Barley is often superior to Oats. Oats from Illinois can not compete at the same price with those from the north and northwest. Barley has given from 5 to $25 \mathrm{per}$ cent more weight of grain per acre in Illinois than Oats and Barley has a much smaller proportion of hull. Last season was the first for many years when scab proved to be a factor in the quality of the Barley crop. Don't go back on Barley because of the one bad year in so long a time.

Seed stock infected with scab should be treated with Ceresan to control the seedling blight caused by that disease. Ceresan also controls the Barlcy stripe disease.

Velvet or Barbless Barley has removed the objection to Barley on account of its beards. Barbless Barley is bearded but the beards are smooth and do not have the barbs which make beards troublesome. We have tried out Barbless Barlcy and found it to yicld as well as the others. A good quality seed is on hand for your consideration.

\section{SPRING WHEAT}

We have both Dark Hard Marquis and Illinois No. 1 spring wheat for your consideration. For North Central Illinois we prefer to use Illinois No. 1 since it is more resistant to scab than Marquis. Marquis is probably superior farther north. Our seed supply of both varietics is above the average.

Sow Spring Wheat early. We have had good results sccding it as late as March and have secn good results with plantings made the first of April. Success with late planted Spring Wheat is a matter of temperaturc and moisturc. The earlier the planting the less chance these factors have to operate against Spring Wheat success.

\section{O A T S}

Good secd oats are scarce. The past season has been very bad for saving seed. Wc have a niec stock of seed on hand and will do our best to take carc of your needs in this line. Don't fail to treat all of your Oats with Cercsan. We arc offering the following varictics: Funk's Great Amcrican, Silvermine, Early Prolific, Iowa 103 and Iowar. 


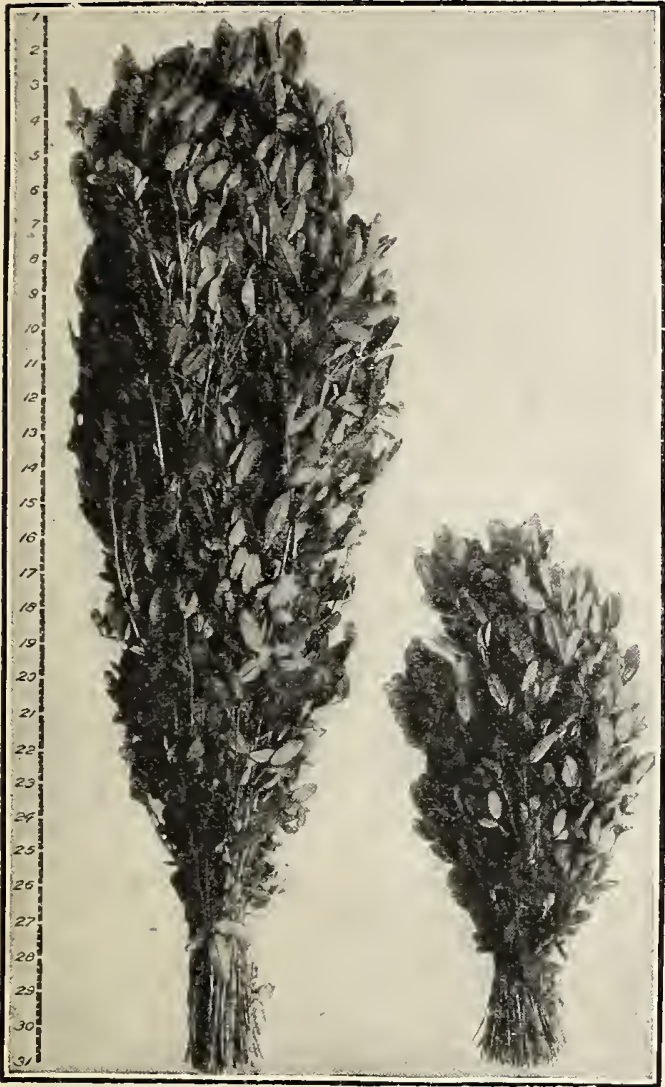

Inoculated SWEET CLOVER

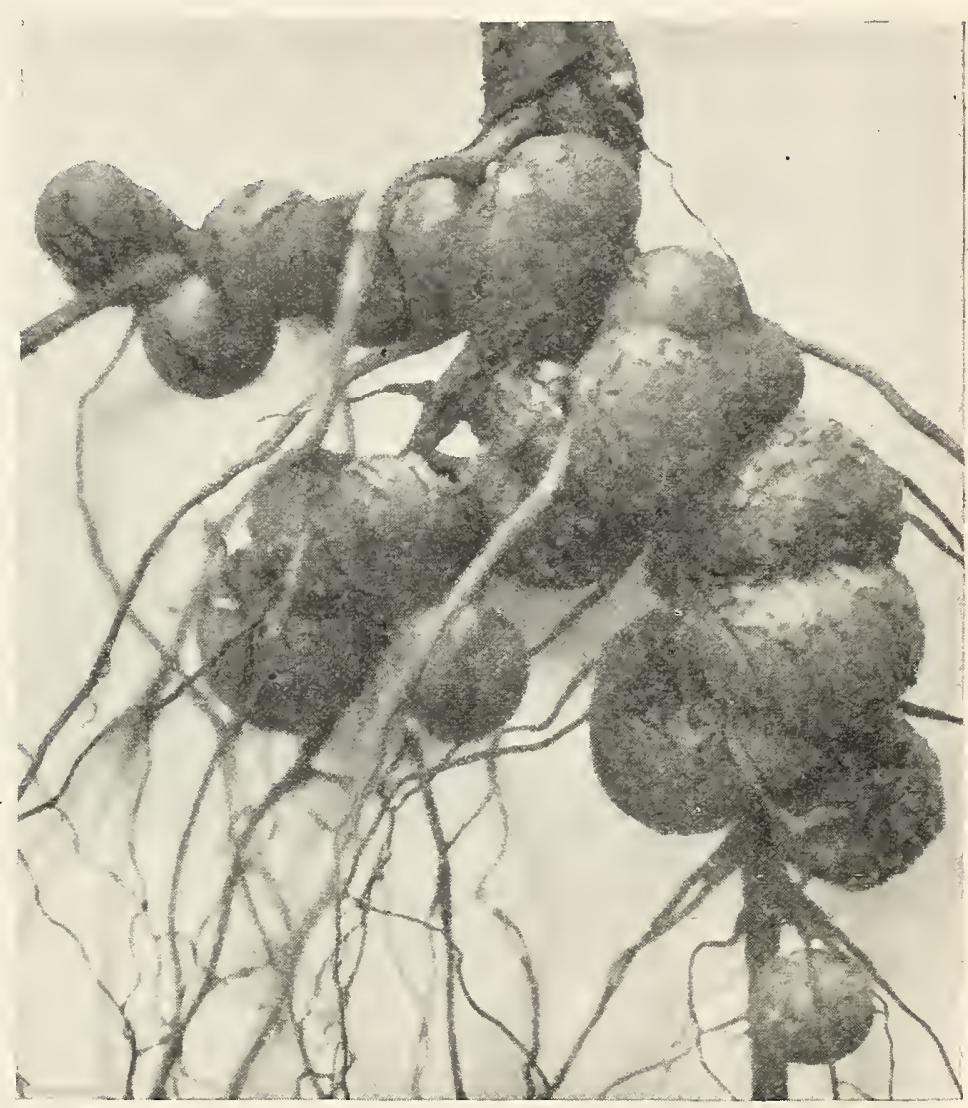

SOY BEAN ROOT, Inoculated

White Blossom Sweet Clover at Arlington, Va., showing the effect of inoculation upon their growth. The plants at the left represent the average growth on the inoculated plats; those at the right the average growth on the plats not inoculated. The plats had been previously limed and were seeded on the same date. Farmers Bulletin 797, U. S. D. A.

\section{INOCUIATION \\ State Kind of Seed You Wish to Inoculate.}

\section{Funk Farms Brand.}

\section{JELLY CULTURE- NEW REDUCED PRICES}

\section{For Clovers and Alfalfa}

$1 / 2$ bushel size inoculates 30 pounds of seed .....\$. 35

1 bushel size inoculates 60 pounds of seed...... .50

$2 \frac{1}{2}$ bushel size inoculates 150 pounds of seed...... 1.00

\section{For Soy Beans, Cow Peas, Field Peas and Vetch}

1 bushel size inoculates 60 pounds of seed....... .50

5 bushel size inoculates 300 pounds of seed....... 1.25

Parcel Post Paid
Inoculate All Legumes Planted. MCQUEEN'S

MOIST OR DRY METHOD MAY BE USED

\section{New Reduced Prices For Clovers and Alfalfa}

$1 / 2 \mathrm{bu}$. size inoculates $30 \mathrm{lbs}$. seed..........\$.50

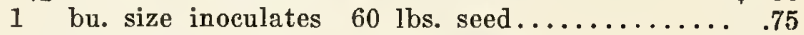

$21 / 2 \mathrm{bu}$. size inoculates $150 \mathrm{lbs}$. seed.................... 1.50

\section{For Soy Beans, Cow Peas, Vetch, Peas} or Beans-all large seed.

$1 \mathrm{bu}$. size inoculates $60 \mathrm{lbs}$. seed............\$.50

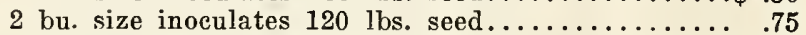

5 bu. size inoculates 300 lbs. seed.............. 1.65

GARDEN PACKET-peas, beans, lima beans, sweet

peas . . ........................ .20

Parcel Post Paid 


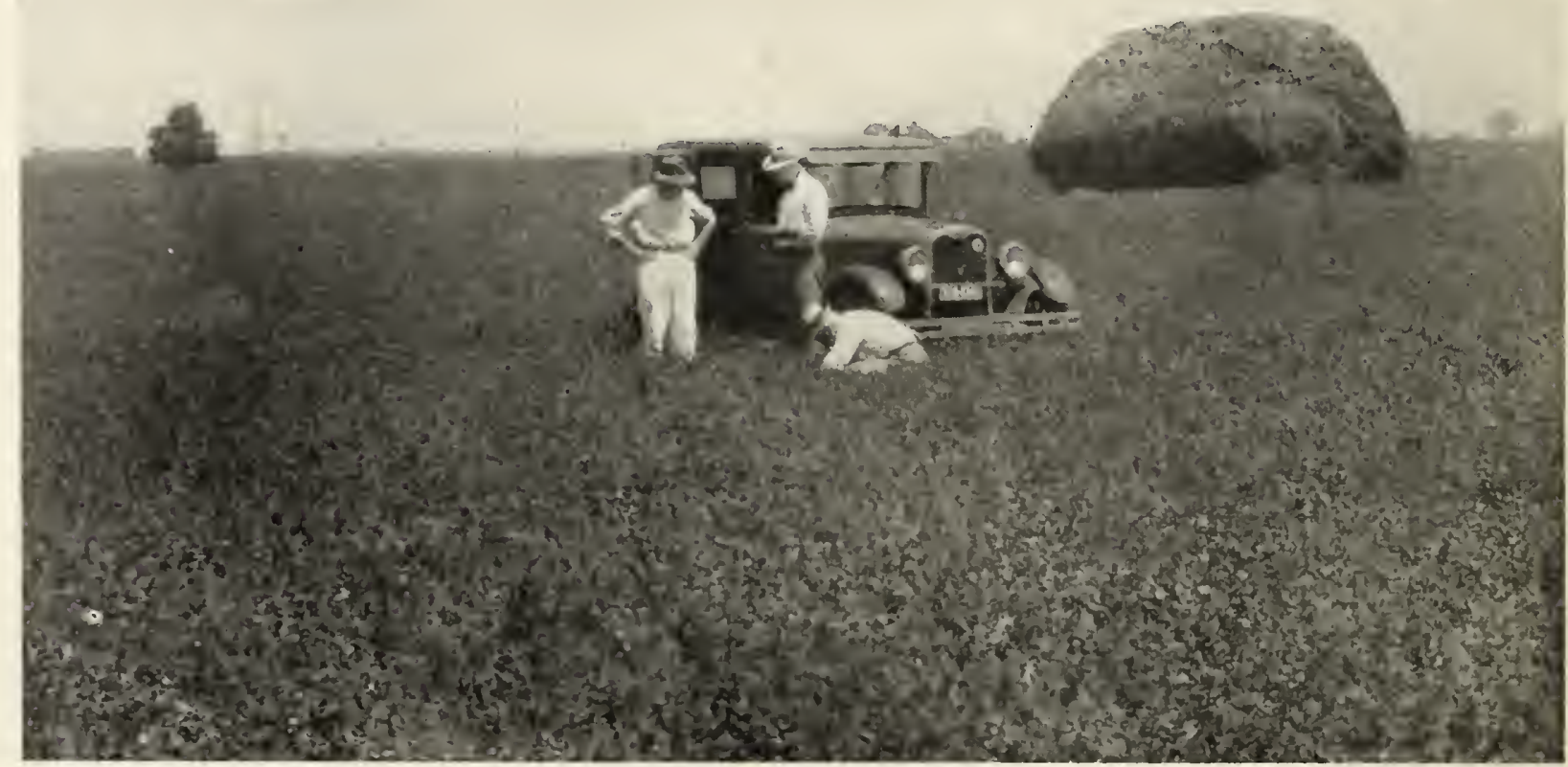

Photo of Frank I. Mann's magnificent 100 acre field of Alfalfa, August, 1928. From the combined viewpoint of technical and practical experience, we consider Mr. Mann the best authority on alfalfa in the Corn Belt. This field was seeded with Utah "BEE HIVE" Pedigreed alfalfa. You will recognize Mr. Mann at the left.

Use Funk Farms Brand Inoculation

Use Limestone Where Needed

ALFALF planting praetiees vary widely. Some farmers seed on winter wheat in February or Vareh while other's seed in the summer. Summel secding usually gives best results on fall plowed land. Sinecessful growers report that manure gives exeeptionally good results on $\mathrm{AL}$ FALEA. The standard rate of seeding is from 15 (1) Is pounds per aere.

Cuttings made too early or too late are hazardous to good stands. Improper pasturage is also iangerous. Firimm . Ilfalfa is a little hardier than ordinary Alfalfa as a pasture erop. Grimm is nsed on the FUNK FARISS where it is to got liard pasture usige. For general use we have found common Alfalfa to be satisfactory. The price of Crimm practically prohibits its use in the Central Corn Biclt.

\section{Hardy "Bee Hive" Utah Alfalfa}

"BEF HIVE" AIFALFA seed eomes from the unile high plateaus of Ltah. It has been there for FIFTY YEARS, isolated, uneontaminated by seed from other regions. Its weak points died out long aro in the severe winters where temperatures often reach 19 degrees below zero, or they have surecumbed to the extreme summer heat of $105 \mathrm{de}-$ grees in the shade.

\section{"Bee Hive" Alfalfa is Hardy}

This seed, traeing baek fifty years to the fields of $\Lambda . \Lambda$. HINKLEY and RICHARD COOPER, is exaetly what the farmers of the Corn Belt need to combat winter killing. No foreign or mild climate seed has ever been mixed with it. "BEE III VE" Alfalfa is liardy. The seed is produeed by the baek country farmers of Utah who have organized for the purpose. 'Their fields are inspeeted and their planting, harvesting, eleaning and shipping is supervised by experts.

\section{"Bee Hive" Makes Good in Illinois}

We liave investigated the place where it is grown. We have investigated its history near the cold topped mountains of Utah. We have grown it here in Illinois and have supplied it to some of the largest farmers in the State. We have found and these farmers have found that it is highly sucecssful. 


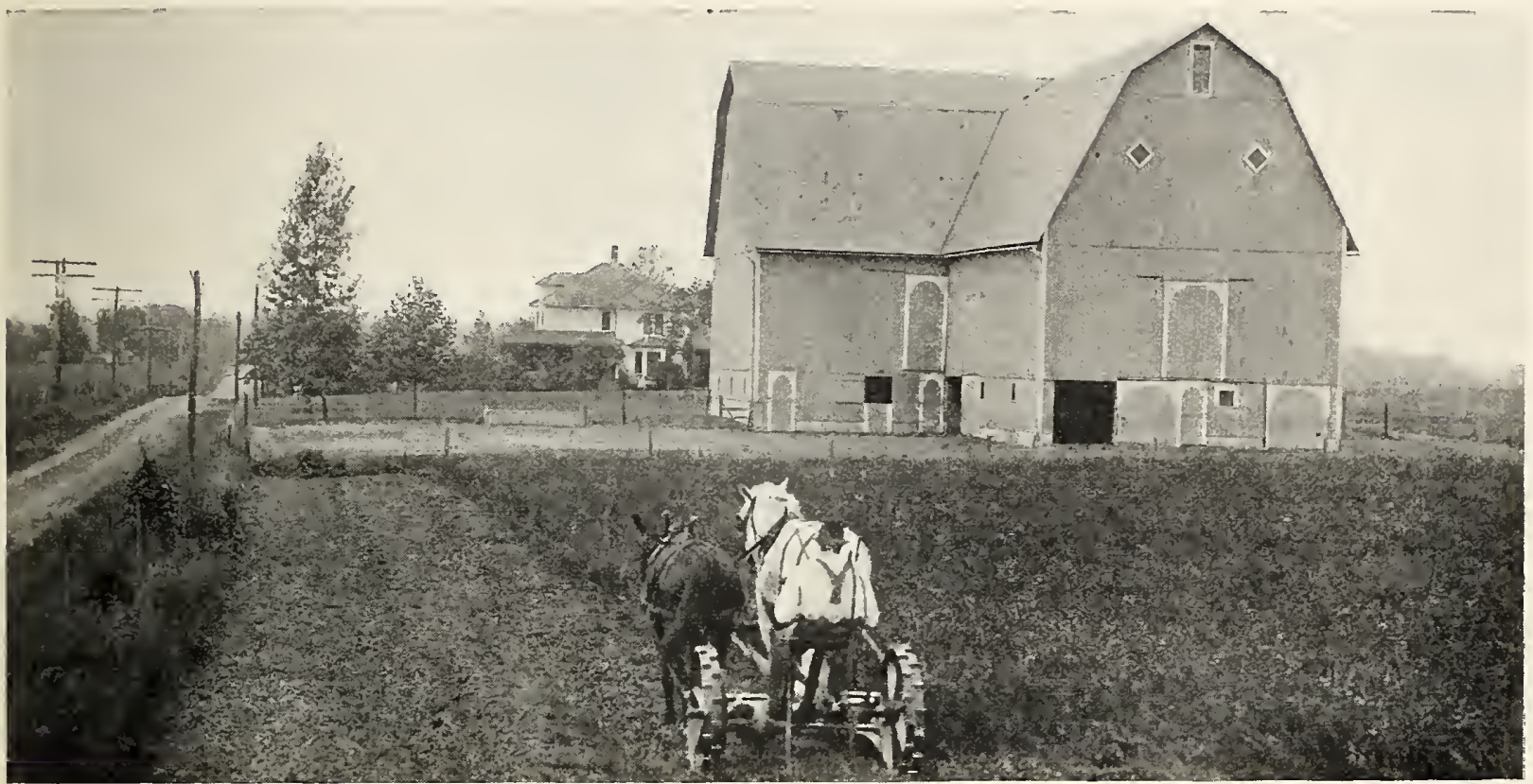

Alfalfa is to the Farmer what the Mother Lode is to the mine. Two or three cuttings of Alfalfa a season is truly a golden harvest. Farm scenes like the above always command interest and admiration.

\section{Alfalfa Is a Superior Legume}

As a high protein hay crop alfalfa ranks first. In the completeness of its protein compounds it seems to be superior to other legumes. In the quantity and quality of the hay it produces alfalfa has no equal. Alfalfa is especially valuable to the beef producer, the dairyman and to the poultryman, and can be used to solve many of their feeding problems. Protein feeds are the measure of their production and with no other crop can proteins be produced so cheaply as with alfalfa.

\section{An Economical Protein Feed}

The production of animal products on the farm, such as nilk, bcef, pork, eggs, etc., is probably accomplished more profitably with alfalfa than with any other feed. The tendency is for the price of mill feeds to go higher. The solution of this problem lies partly in the production of more alfalfa. Because of the high percentage of protein, the feeding quality of this protein, the large amount produced per acre and because of the value of the mineral compounds it contains, alfalfa is the real key to the economic production of animal products.

\section{Alfalfa Enriches the Soil}

But, the foregoing is just one-half of the alfalfa story. Alfalfa, aside from being the best legume to grow for hay, is the best of the deep rooting legumes to grow for a soil improvement crop. It is by far the best to grow when it is to be used for both purposes. In fact, alfalfa is the only legume perfectly adapted to both purposes. No other legume is as valuable as alfalfa in increasing the fertility of the subsoil. Alfalfa, in its preparation to live over winter, translocates food and fertilizer material from the tops into the roots. In order that the maximum amount of organic matter and fertilizer material be kept in the subsoil, the alfalfa should be plowed in the fall after it has made preparation for the winter.

\section{Increases Subsoil Fertility}

Mr. Frank I. Mann reports that, "Where alfalfa has been used in this way for eightecn years in rotation, (4 year rotation) analyses showed that there had been an increase of Twenty Tons of organic matter per acre in the subsurface soil7 to 20 inches in depth-and a large increase in phosphorus, sulphur and other elements." The building up of the subsoil fertility leads to greater crop yiclds. The hazards of dry weather are reduced. The use of alfalfa makes for a more profitable, more prosperous and more permanent system of agriculture. It pays to grow alfalfa. 


\section{The Plea of the Soy Bean}

Give me just a few of the years-Just a small amount of the patience, time and money spent in rescarch-Just a fraction of the experience gained in a hundred years of growing coln, oats and wheat.

Give me some of the opportunities you have given the crops you want to compare me with.

You have taken nuc without much more acquaintance than an introduction, given me a depleted soil and asked me to restore the nitrogen and compete in cash returus with crops you have grown for years under the most scientific methods.

Again, I plead, give me just a portion of the experience you have had witlı other crops and I will prove my value.

Give me a succession of crops as you give corn and sec me get stronger instead of weaker.

Give me the credit of improving soil and not depleting it.

Give me a chance to feed your stock with the highest protcin feed you grow.

Give me the opportunities I plead for and you will proclaim me the farmer's' best friend,

Signed,

\section{SOY BEANS}

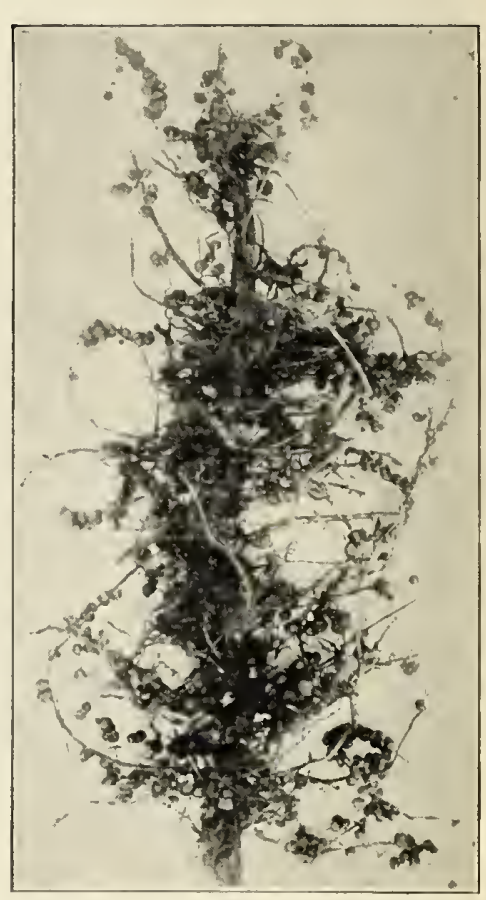

Roots of soybean plant showing abundant development of nitrogen nodules, the result of proper inoculation of seed and proper soil conditions.

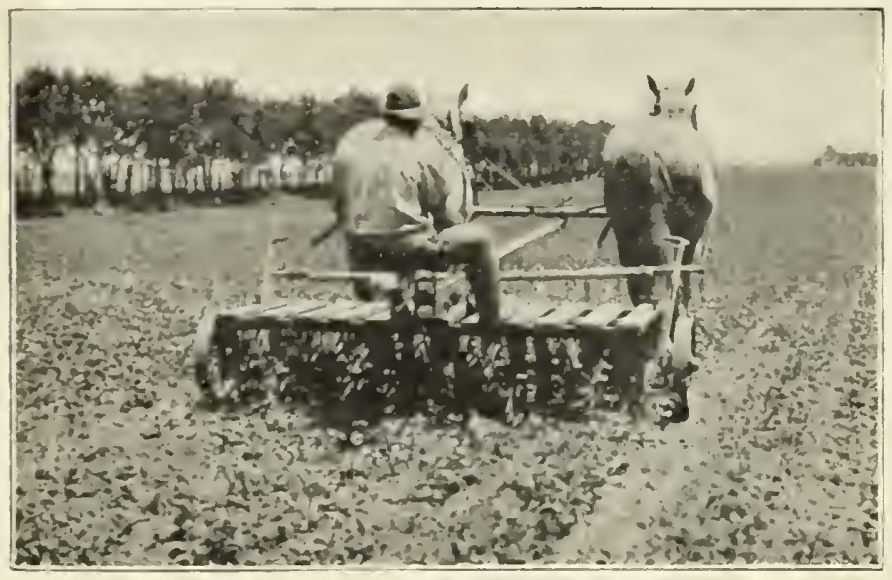

The picture above shows a field of Soy Beans planted in rows with a drill and cultivated screrely with a peg tooth harrow and rotary hoe. This picture shows that beans can be grown successfully this way but only under one condition and that is, that they must be cultivated thoroughly, planting a bushel to a bushel and a half of good seed to the acre.

\section{Must Inoculate for Maximum Yields}

Soy Beans will yicld well only when there is thorough inoculation. Only Soy Bcan bacteria will do. Soil from an inoculated ficld where Soy Beans liave recently becn growll offer's a satisfactory and economical means of inoculation.

Commercial cultures, such as Funk Farms Bland Inoculation can be purchased at small cost and is a very sure means of successful inoculation.

Yiclds increase with thorough inoculation. Inoculation inereases the nitrogen in the plants, the fertilizer constituents in the roots, and the protein in the beans.

\section{SOY BEAN MILLS ASSURE A MARKET FOR CROPS WE OPERATE A MILL}




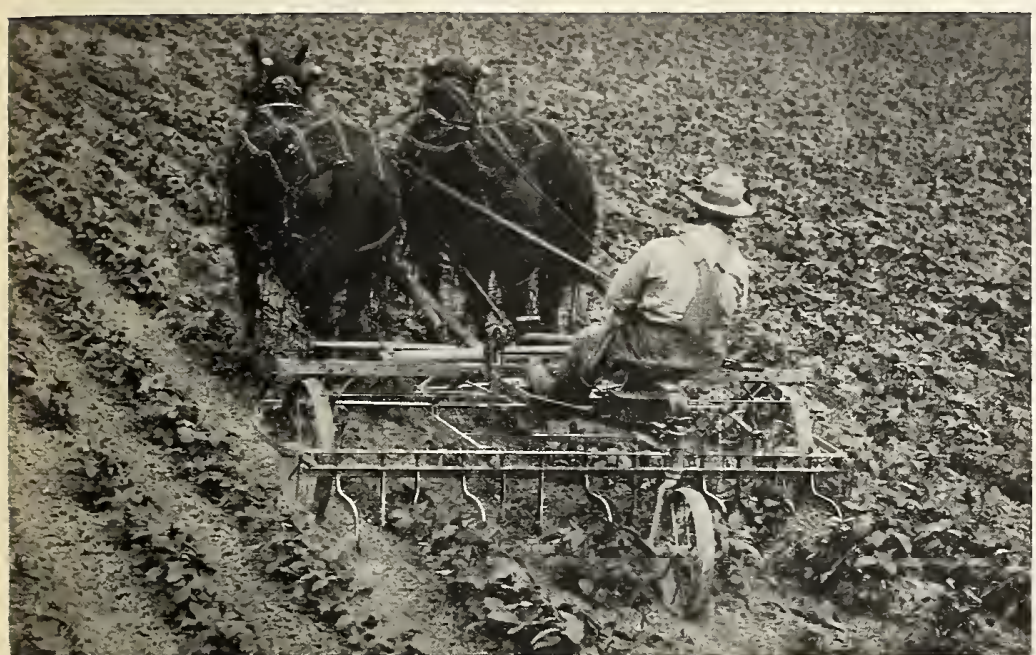

\section{SOY BEAN HAY}

Each year the popularity of this fine high protein hay increases. It is an annual which can be used as a catch crop or substituted for some other erop in the rotation. Two to four tons of hay per acre may be expected.

Two bushels per acre, drilled solid, about the middle of May, harrowed or rotary hoed at the proper time and they are laid by till harvest. Cut after the pods are fully developed but while they are still green. Soy Bean Hay is also gaining favor as a roughage for hogs, growing pigs, young cattle and sheep. It makes an excellent winter feed for horses.

\section{Funk's Soy Bean Hay Mixture}

Our mixture contains such varieties as Ebony, Wilson, Sable, Virginia, and sufficient early maturing yellow varieties to permit cutting while the leaves are still on and yet obtain ample grain.

\section{No Odds and Ends at Funk's}

It has been erroneously stated by some that the only excuse for haymixture is to dispose of a job lot of odds and ends of varieties at a favorable price. This is not true at Funk's. We operate a Mill and are able to dispose of all small lots of beans, splits, cracks and inferior seed beans profitably by milling them. We are able to give you high quality plump high grade seed. Our Hay Mixture has proven itself and has been especially popular in the dairy section of the State. It is invaluable to the man who needs a high protein roughage on short notice.

\section{VARIETIES}

Some of the most popular commercial varieties are:

MANCHU, A. K., MIDWEST, ITO SAN, and for hay and fertilizer: BLACK WILSON, BLACK EBONY, SABIE, VIRGINIA.

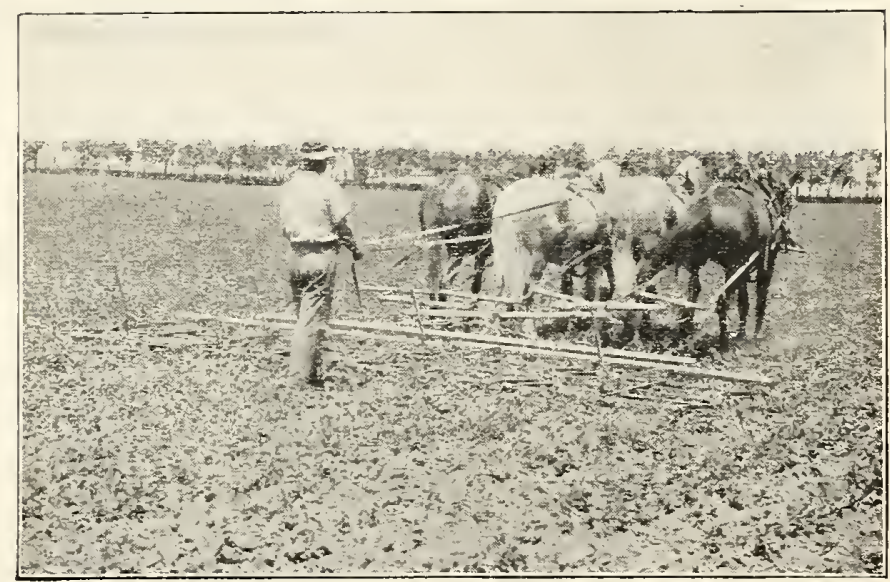

\section{SOY BEAN MILLS INSURE A MARKET FOR CROPS WE OPERATE A MILL}




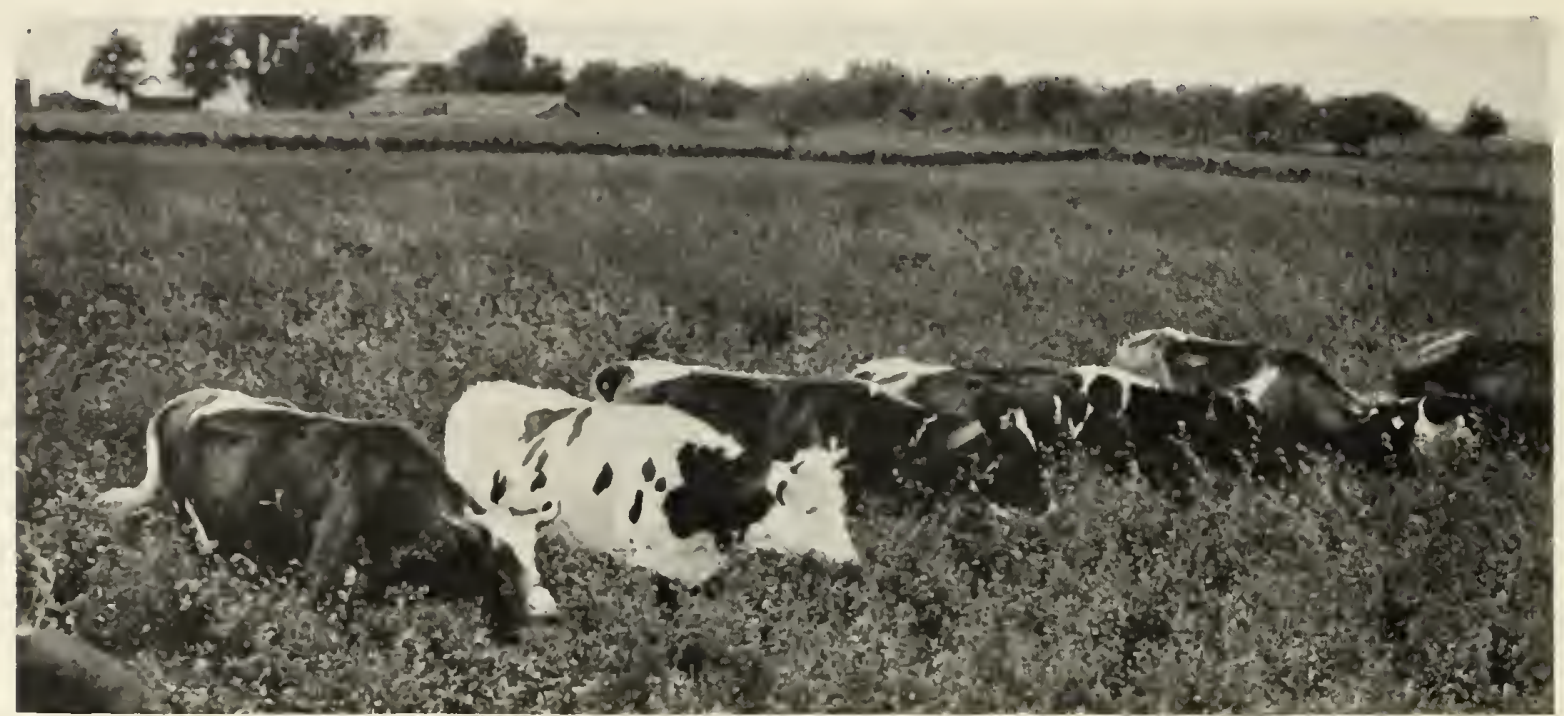

HOLSTEIN CATTLE ON SWEET CLOVER PASTURE. ALL STOCK LEARN TO LIKE IT.

\section{USE FUNK FARMS BRAND INOCULATION}

\section{SWEET CLOVER}

SWEET CLOVER is the king of all soil improvement crops. It fits into any rotation and is extremely good in a livestoek rotation. Where Blue Grass keps one eow, Srrect Clover will earry three. All stock learn to like Sweet Clover.

From 12 to 15 pounds per are is a standard rate of seeding. Sweet Clover can be sowed broadesst as early as February. It is common practice to sow it with oats. A better stand would probably result if it was broadeast and harrowed lightly after the oats lad been disced in so as not to cover the Sweet Clover too deeply. Moisture is seldom a factor in enrly spring planting. Sweet Clover seeds are small and lack the food reserves to send the small seedling through a deep covering of soil. It is claimed that Sweet Clover broadeast after the eorn is laid

\section{USE LIMESTONE WHERE NEEDED}

by has considerably more than an equal chance of resulting in a good stand. Moisture is a big factor in this method of planting. The rotary hoe and corrugated roller are useful tools for covering Sweet Clover sinee they are less apt to cover too deeply.

Sweet Clover sowed in the small grain and plowed under in the spring makes it the best green manuring erop of all the legumes. P'roperly inoculated it has been found to fix three to four times more nitrogen than red clover. The deep rooting habit is a strong point in its favor. The roots go down and absorb plant food from lower levels than do most erops. This plant food is translocated into the above ground parts of the plant. Later these plants are plowed under into the surfaee soil where the shallower rooted plants ean niake use of the plant food otherwise not available to them.

\section{Grundy County Sweet Clover}

Grundy County Sweet Clover is an earlier maturing, smaller type, heavier seeding strain of the White Blossom Sweet Clover developed in Grundy County, Illinois. It is extremely winter hardy. Grundy County Sweet Clover makes an excellent hay since it sends out fine leafy branehes which are relished and readily eaten by all livestock. Grundy County Sweet Clover has been used mixed with the later maturing white blossom strain in order to provide an early pasture. It is a fine eombination of soil builder, hay and pasture erop. We recommend sreding at the rate of 12 to 15 pounds per aere.

\section{HUBAM S WEET CLOVER}

Hubam Sirept Clover is an annual, and on well limed fertile land will make a very satisfactory growth and ean be sown in the spring like any other elover and seed harvested the same season. The earliness which the plant begins to bloom after seeding compared with the long season which it will remain in bloom makes it very desirable as a bee pasture and bee kecpers are enthusiastic about it. It is claimed that II uham produces more honey than any other elover known and is of excellent flavor and quality. 


\section{Red Clover \\ Use Funk Farms Brand Inoculation}

The use of high quality seed always pays best in the long run. Red Clover has always been popular with the Corn Belt Farmer as a hay, pasture and soil improvement erop. A legume should always be a part of a good crop rotation and Red Clover has filled that need for a longer time than any other legume. There should be a larger acreage of Red Clover planted. It is not so exacting in its needs for lime as alfalfa and sweet elover and it can be readily worked into any rotation. The first cutting makes a fine grade of hay which finds a ready use on most farms. The second cutting can be made early and used for hay if the hay crop is short. It may be satisfactory for a seed crop or it can be plowed under and used as a green manure.
Red Clover deserves a larger acreage than has been allotted it in the past few years. Only 7 to 9 pounds of seed are required per acre. No doubt many poor stands and failures of recent years have been due to soil acidity. Our soils are constantly being depleted of lime and becoming more acid. Much land that grew a crop of Red Clover in the past has had a large amount of lime leached from it until at the present time it is not a favorable soil for Red Clover. Proper inoculation is an aid in securing a good stand of Red Clover. It is too often taken for granted that there is inoculation in the soil for Red Clover and at the small cost for inoculating the seed this assumption may prove very costly. Inoculate all legumes planted and remove this factor in securing a good stand.

\section{Alsike Clover \\ Use Funk Farms Brand Inoculation}

Alsike Clover will grow on slightly acid soil and for that reason many farmers mix alsike with their alfalfa and red clover. Alsike will eateh on many sour or poorly drained spots in the field and thus make for a more efficient land utilization. Alsike makes an excellent pasture crop and has the added advantage of being a perennial erop which can be left down for several years. Alsike Clover is an especially fine hay crop and finds a place in many hay and pasture mixtures. It is a good legume to grow with Timothy. In dry years Alsike does not do as well as Red Clover but it is much more satisfactory than Red Clover on wet, poorly drained or bottom land.

\section{Mammoth Clover \\ Use Funk Farms Brand Inoculation}

Mammoth Clover is similar to red clover both in appearance of seed and in habit of growth. It is later maturing and grows larger than red elover and for that reason is superior for a soil improvement crop. It is well adapted to use on thin soils.
MIammoth Clover is a good variety to seed with Timothy since both mature at about the same time. Sow 8 to 10 pounds per acre by itself or 6 pounds of Mammoth Clover and 8 pounds of Timothy per acre makes a good mixture.

\section{Woods Clover [Dalea]}

A Legume for Thin Sour Land

Woods Clover is an annual legume which will grow on thin, sour or sandy land. It does not prove satisfactory on more fertile soils. In case Alfalfa or Sweet Clover will grow and do well use them. Woods Clover is for land which will not grow Alfalfa, Sweet Clover, or Red Clover and it is on this type of soil that Woods Clover seems to thrive. Reports from Iowa, of fourteen tons of green material per acre, indicate that this legume is an excellent green manure crop.

Woods Clover is an abundant seed producer. Iowa growers report from eight to twenty-three bushels of seed per acre. The erop is seeded in small grain in exactly the same manner as other clovers. About 12 pounds of seed should be used per acre. It is not advisable to seed too early in 
the spring sinee this legume is somewhat of a warm weather erop.

Woods Clover should be inoeulated before seeding as is the ease with all legumes. Commereial Cultures specially prepared for Woods Clover or Dalea should be used. Inoeulation for no other legume will inoeulate Woods Clover. Woods Clover is in a elass by itself. Unless legumes are inoeulated they are of little benefit to the land. In faet, it is elaimed that uninoeulated legumes are soil robbers.

\section{Rape}

Genuine Broad Leaved Holland Grown Dwarf Essex Rape is the best and will produee the most feed. Try some of our Holland rape this year and you will not be disappointed.

Rape secded witl oats provides summer pasture in place of foul weeds. Rape is good for hogs, sheep, eattle, ealves and horses. Rape may be grown alone or with small grain or between eorn rows at last eultivation.

\section{Red Top}

This is one of the best grasses we know of to seed poorly drained land. It makes good pasture and as the priee is very reasonable this year, suggest that you try it out on your low spots. You will be surprised how it will eateh, and what it will produee on land which you may now eonsider praetieally worthless. Be sure and order a few pounds this year and give it a trial.

\section{Millet}

It is easy to obtain a good stand of Millet either by using a grain drill or broadeasting at the rate of 30 to 40 pounds of seed per aere. German or Golden Millet produees a larger yield of hay and we reeommend thesc varieties for average Corn Belt conditions.

\section{Timoth y}

We have exeeptional stoek of home grown timothy this year. It is bright, plump, high germinating and price is right. Timothy is easily established and does especially well with red elover or alsike.

\section{Kentuoky B1ue Grass}

Kentucky Blue Grass has three main uses in the Corn Belt. First-as a pasture mixture it occupies a very strong position. Seeond-it is the basis for all lawn grass mixtures. Third-as a grass for establishing a permanent sod along the highways it has no equal.

Seed this year is moderate in price, quality is excellent and now would be a favorable time to place your order.

\section{Hay and Pasture Mixtures}

There is a.real place on most farms for a hay and pasture mixture. Where several different hay plants are grown together the tomage of hay is often inereased and, too, it is possible to eombine the good points of more than one plant in this manner. That small lot would make an exeellent plaec for our hay and pasture mixture.

We will be glad to make recommendations for mixtures for speeial uses and for use under eonditions which are out of the ordinary.

\section{Funk Farms Mineral Mixture}

IIAS proven its value in the feed lots on the Funk Farms.

CON'TAINS Spent Bonc Black--Calcium Carbonate-Kiln Dried Salt-in the proportions outlined by the Iowa Experiment Station. Cost is small eompared to gain. It's a money maker fed to hogs. Prieed at $\$ 2.50$ per hundred pounds.

\section{Hog Pastures}

Rape sceded with oats makes a superior summer hog pasturc and takes the plaee of weeds in the hog lot. Sudan Grass is exeellent for a later hog pasture. A field divided into smaller lots would makc for better utilization of these erops for hogging. Best results are obtained when the hogs are not turned on the pasture too early. That barren hog lot sceded to one of these erops or mixtures will make a fine place to earry the hogs over till the eorn is ready to hog-down in the fall. The sanitation advantages are obvious.

\section{Sudan Grass}

Sudan Grass belongs to the Sorghum family. It was sccured from Khartum, Sudan, in 1909. It seems to be adapted to any soil and most elimates. It will produee two cuttings of hay the same year and under eertain eonditions may be eut the third time. The yield averages three to five tons per acre and stoek eat it in preferenec to almost any other kind of hay. It is a suecess for a pasture crop. It makes a sure summer pasture within thirty days. Best growth is seeured in hot dry weather when other pastures fail. 


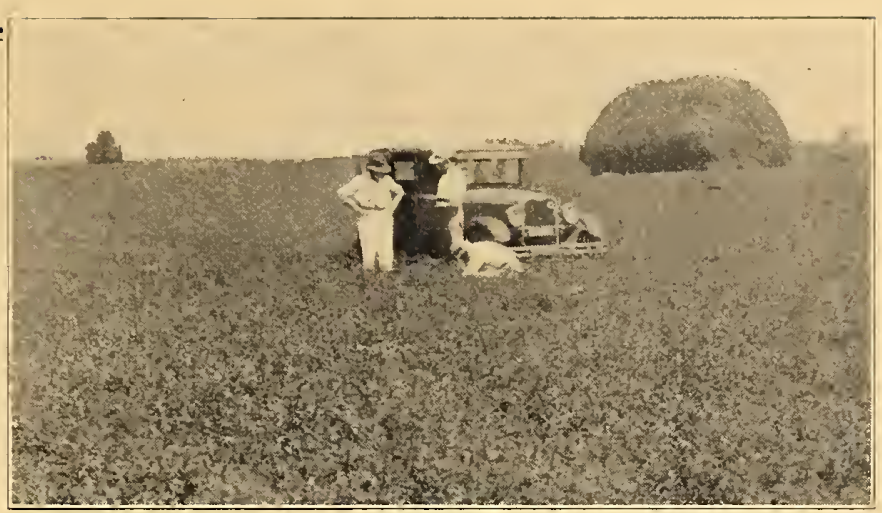

Photo of Frank I. Mann's magnificent 100 acre field of Alfalfa, August 1928. From the combined viewpoint of technical and practical experience we consider Mr. Mann the best authority on Alfalfa in the Corn Belt. This field was seeded with Utah "BEE HIVE" Pedigreed Alfalfa.

\section{Cultivated}

By a group of over 2200 farmers.

Under a unique contract system.

With organized expert supervision.

The fields are selected and weeded.

The seed harvested, again selected, then recleaned, refined and tested by the latest improved methods.

The Alfalfa seed which comes to you under the Bee Hive Brand is the result of supervised production under organized direction. The fields are the result of seeding and reseeding from the first local production since the time before the Spanish-American War. The system of contract production, harvesting methods, seed cleaning and testing, absolute native pedigree and other details are things that only this organized effort can insure.

This system of contract production of Alfalfa seed is distinctly novel in the field seed industry. Although in general it is practiced in the garden and flower seed trade, nothing quite like it is practiced in common in the field seed industry.

THE RESULT IS THE PRODUCTION OF BEE HIVE-The Cream of THE UTAH CROP - the best, proven seed of its strain on the market, with a known history of thirty years behind it.

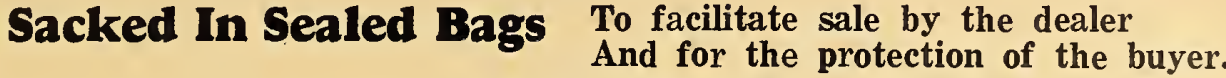

\section{A Premium Seed} tions.

The hardiness of Bee Hive is field-bred through years of adverse climatic condi-

The quality of Bee Hive is field-developed by the organized co-operative effort of over 2200 farmers. seed.

The qualities of Bee Hive are grown in it. It is more than merely Factory dressed

\section{Proven by Test}

Extracts from original official correspondence on file:

"This spring we decided to purchase additional carloads f this same Utah seed to supply planters where unfortunately other varieties and Southwestern Alfalfa had not withstood the freezing-Reports are already coming in, indicating the pleasure of the farmers and planters have in the result of this seed distribution."

"Nine men picked Bee Hive for Grimm-All expressed themselves as being in favor of Bee Hive from the results of this demonstration."

"I am personally a strong believer in Bee Hive Alfalfa seed as we have conducted some very good demonstrations in the county, along with the best Grimm we could buy. I recommend it in preference to Grimm."

"About ten different fields were visited and the consensus of opinion seemed to be that there was very little, if any, difference between Dakota 12, Utah and Grimm

Alfalfa as to resistance to heavy winter killing, condition of growth and stand."

"I have examined the field three or four times and can find practically no appreciable difference in the growth and development of the different varieties. condition at this time when so many Alfalf it in condition at this time when so many frozimm, Dakta 12 Grimm, Dakota 12 and Bee Hive Alfalfa seed.'

"Utah Alfalfa at the Michigan Experiment Station has yielded an average of 3.98 tons per acre for six consecutive years."

"Michigan with 600,000 acres has the largest Alfalfa acreage of any state east of Kansas and Nebraska. The majority of Michigan's Alfalfa acreage was sown with Utah seed."

\section{FUNK BROS. SEED CO. \\ Bloomington, Illinois}




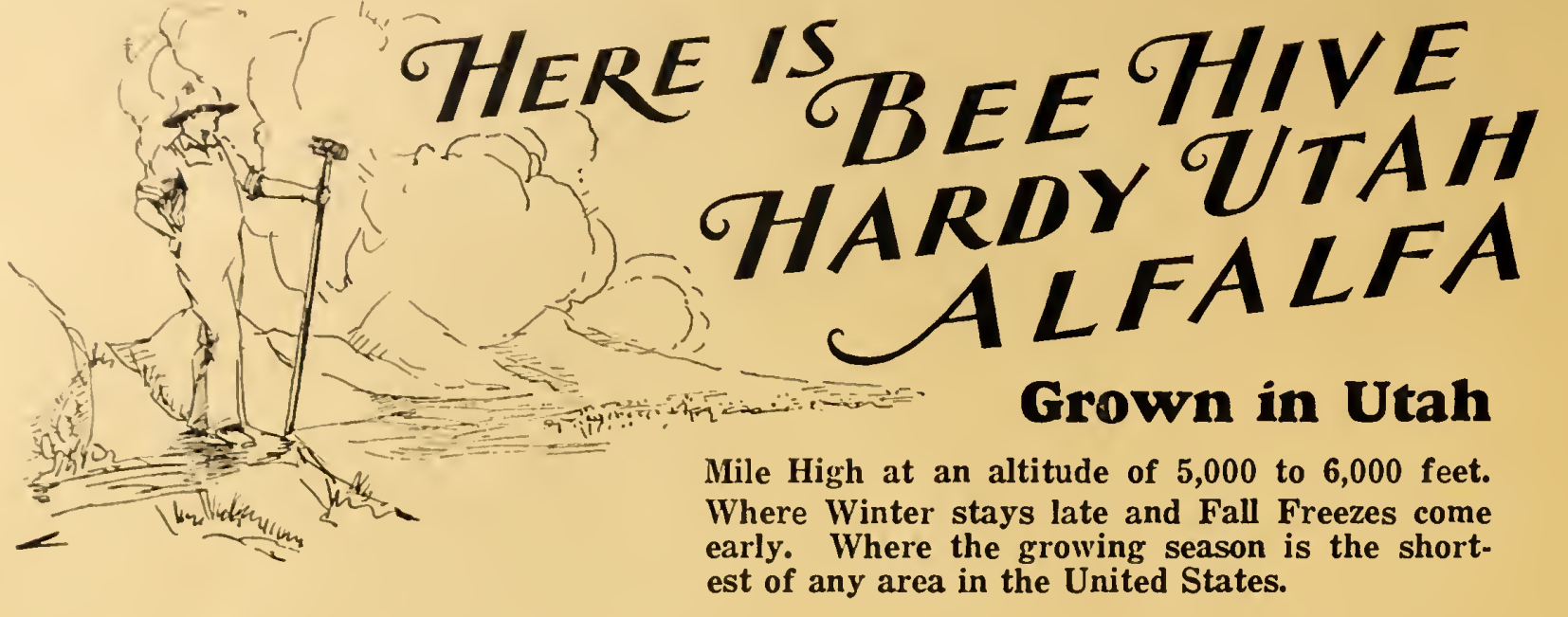

W HEN you were a boy did you ever go out and climb to the top of a windmill in 7 January when it was $10^{\circ}$ (degrees) above zero on the ground? Didn't you notice how much colder it was at the top of the windmill?

Well, how would you like to climb up a mountainside until you were, not $30 \mathrm{ft}$., nor $300 \mathrm{ft}$., but 4,500 to $5,500 \mathrm{ft}$., where the minimum temperature is from 10 degrees to 20 degrees below zero instead of above?

The higher you go in the air, the lower the mercury goes in the thermometer. SEVERE CLIMATIC CONDITIONS DEVELOP WINTER HARDY PLANTS.

\section{Produced from 30-Year-01d Fields}

From plants that have survived severe winter conditions year after year for thirty plant generations, subject to the hazards of icy mountain WINTERS. NATURAL SELECTION.

Resisting temperatures of from $20^{\circ}$ to $30^{\circ}$ (degrees) below zero with scanty snow protection and the even more damaging spring freezes and thaws. RESISTANCE.

The survival of the fittest-with a longer natural pedigree than any other domestic origin. PEDIGREE.

It can be readily seen that Bee Hive seed is produced from sturdy stock, the hardy long living plants that have gone through annual survival of the fittest periods for thirty years. Plant life that can survive through thirty years of hardship proves itself. What weaklings there might have been have eliminated themselves without man's help years ago. It is just as if you had a crew of men at work constantly in your fields for thirty years, pulling up, throwing out-eliminating the weak plants-leaving only the strong, virile ones--so ONLY THE FITTEST HAVE SURVIVED.
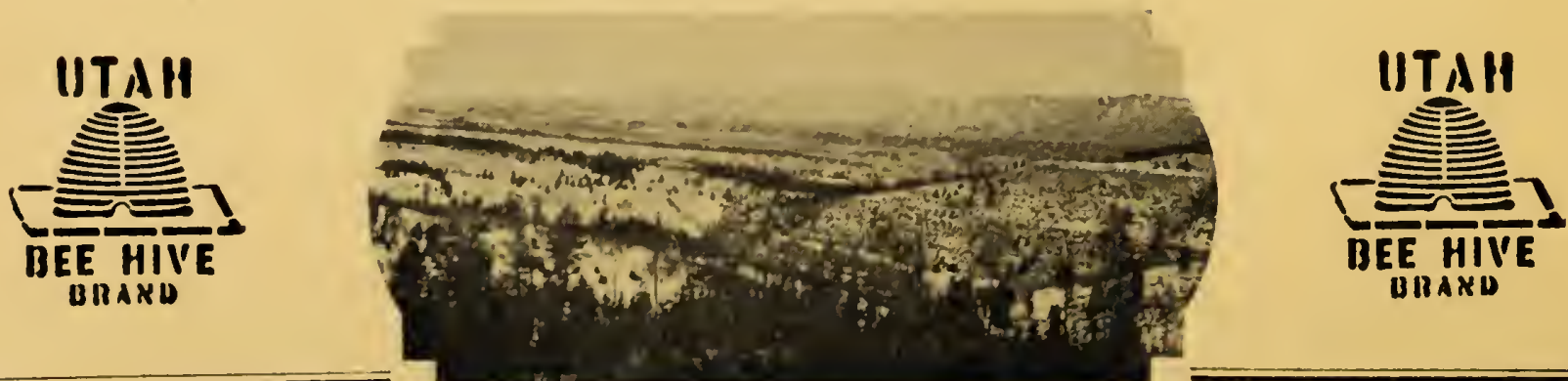


\section{Funk Farms Inoculation}

For Clover or Alfalfa, 1 bu. zize, 500

For Soy Beans, Cow Peas, Vetch, etc., 5 bu. size, $\$ 1.25$

State kind of seed you wisb to inoculsta.

See catalogue page 15, for Detailed Price List. Ask for Special price on 10 Bushel lots or over.
3

\section{McQueen's Inoculation}

State kind of seed you wish to inoculate.

For Clover and Alfalfa, 1 bu. size, $75 \mathrm{c}$

For Soy Beans, Cow Peas, Vetch, etc., 5 bu. size, $\$ 1.65$

See catalogue, page 15 for detailed price list. s.

\section{Funts Special \$2.00 Seed Corm Orfer}

\section{Sativeration Garamtaxd}

\section{FOUR STRAINS-ENOUGH TO PLANT ONS-EIGHTE ACRE OF EACH. INCLUDFS $\triangle T$ LEAST TWO OF YUNES FAMOUS BYBRDS. $\$ 2.00$ FOB FED LOT POSTPAD. CHICE, WITH ORDER. TELTOW. DISEASE EREF. IREATED.}

Every iarmer should place an order. Try out Funks Famous Hybrid strains of corn. Plant them early, watch them grow. Cold resistsnce, vigor, high yields, combined with quality, have been bred into these new products of science. They are the latest word to date, quality and yield considered. We have unlimited faith in their performance if planted on land capable of producing corn at a profit. Which strain is best adapted to your farm can only be do. termined by test.

Plaos your order early-compare these straing with the other corn on your farn. Plant it where you can watch it grow, where your friends can see it, where the boys ean see it from the tim it peeps out of the ground until it is ready to harvest. Treat it right and if you tell us next fall it was not one of the most interesting experiments as well as one of the best investments you erer made your purchase price will be cheerfully refunded.

The Sample Package will contain at least two Eybrids selected to suit conditions in your locality. Satisfy yourself as to the superiority of Hybrid corn by growing it yourself. The cost is negligible. We have produced more of this corn this year than ever before. The demand has always exceeded the supply. Only a limited amount is available for use in the Sample Packago.

Funk's originated the Utility Type corn so widely grown at the present time. There is no question as to the superiority of Utility Type Corn. Use these open-pollinated varieties to put some new corn blood into your best cash crop.

\section{ORDER FOUR PACEAGE TODAY BEFORE THE SUPPLY IS EXHAUSTED}

\section{Improved Seanesan Jr.}

\section{Dust Disinfockert for Cors}

1 1b. treots 8 bushain

1. 1b. 站 $\$ 1.75$

lbse at \$1.75 per 10. \$

\section{Ceresan}

For Osta, Whent, Barley and Rye

Oats and Barley use 3 oz. per bu.

Wheat and Rye use 2 oz. per bu.

1 lb. tins, $75 \mathrm{c}$.

$5 \mathrm{lb}$. tins, $\$ 3.00$.

$75 \mathrm{c}$ tins

$\$ 3.00$ ting

$\$$

Dr. WIIson's Dust and Spray Masks. Protects the zose, mouth, throat and lungs. 


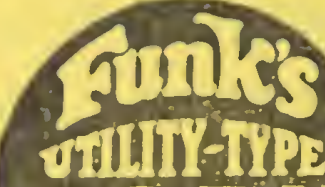 Q -20 Gromine \\ A Good Place to Buy Seed Funk Bros.Seed Co. WHOLEEALE and RETAIL Bloomington, Illinois} "erifod sor ifines?

Fobrasy 20, 1929

TERMS OI SALE:

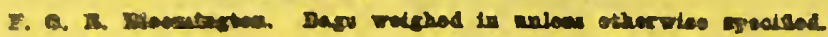

CASE WITH O3DXB or C.O.D. vith Inspection allowed - Prices subject laportant market changer -

FUNB BROS. SEED CO., Bloomington, IIl.

ORDER BLANK

Dete

Enclosed find. for $\$$

for which ship mo goods aseked on this order blenk: Eemittances may bo mado by chock. P. O. ordar, express money order

Mis Name.

P.O. Stato

Counts. R.F.D

R.R Ship by To Shipping Poins

Remarks:

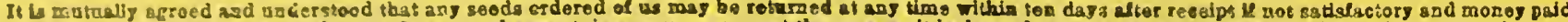

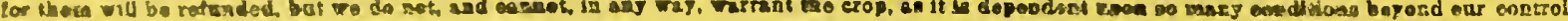

\begin{tabular}{|c|c|c|c|}
\hline $\mathrm{Bu}$ & $\begin{array}{l}\text { 38gs Included Gross for Net W aight } \\
\text { Onlous otherwise specifed }\end{array}$ & $\begin{array}{c}\text { Price } \\
\text { per ba. }\end{array}$ & \\
\hline
\end{tabular}
SEED CORN

Forrg Hrons Cors (Sold or:ly tested, shelled and treated.)

Funks Pure Line Doublo Crosa No. 250 . . . . \$15.00

Funks Hybrid No. 365

Opas-poluinatmo Varieztes

Average Germinstion 95 to $98 \%$

Ear Corn 80 eonts per bushel higher

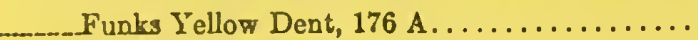

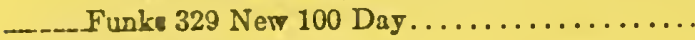

Funke 90 Day Yellow.

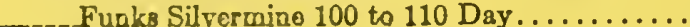

Funks Gold Standard Leaming. . . . . . . . . . . .

Krug Yellow Dent, 100 to 110 Day...........

Golden Fing-Yellow Dent 100 Day........

Will Cousty Favorite 90 to 100 Day Fellow Dent

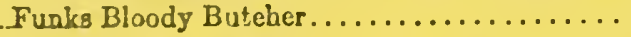

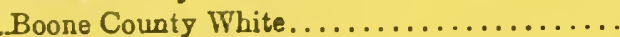

The above varieties Tested for Vigor and Free-

dom from Diserne....................

Funks Silago Corn. ...................

A sk for special prices on 10 bushels or over.

\section{CLOVER}

I. YOU DESIRE HICHEST CILDE OBTALNABLE DAE POH FUNEB FAKM BRAND

We do not gande Foreian Clover Seed

Rod Clover

Funk Farms Brand . . .................. 22,00

_. Good Value................... 21.00

Mammoth Clovar.....................

Alrike Clover

Funk Farm Brand...............

Good Value...................

Whito Bloseom Sweat Clover

_. Funk Farm Braad $\{21 / 2$ bu. bags $\} ..$.

_._. Good Value....... $\begin{gathered}23 / 2 \text { bu. bags } \\ 22 \mathrm{e} \text { eaeh }\end{gathered} \ldots$

Grundy County Sweet Ciover

Fuak Farms Brand $\{21 / 2$ bu. bags $\} ..$.

_._.Good Valuo....... $32 \mathrm{c}$ each $\}. .$.

Whit Clover (amall) ................ per lb.

Hubaro Sweet Clover.................. 16.50

Wood's Clover (for thin, sour land).........

Ask for special trieces on 10 bushels or over.

\subsection{0 \\ 22.50 \\ 21.50}

6.50

6.50

6.00

9.00

Bus.

\begin{tabular}{c|c}
$\begin{array}{c}\text { Prico } \\
\text { per ba. }\end{array}$ Amt. \\
\hline
\end{tabular}

\section{ALFAIFA}

BARd aNd Frez Pross Noxjotgs Werds

"Bee Hive" Utah Pedigreed Alfalia. Comes in original one bushel sesled bsga, U. S. Gov't.

Verified Origin. Any quantity deaired........ \$18.00

Northwestern, Funk Farms Brand.......... 17.50

Montana Sealed Grimm................. 27.00

Montans Rogistored Grimm............ 28.00

Idaho Registered Grimm............. 28.00

Blaekfoot Grimon.

Ask for apecial prices on $10 \mathrm{bu}$. or over.

\section{SOT BEATS}

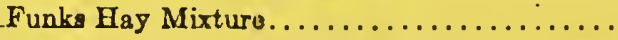

Manchu, Illini, A. IK. Midwest, Ito San, Black Eyobrow, Ebony, Wilson, Virginia, Sable A se for prices

\section{OAT8}

Extea BuIght-Recleantd

Iowa 103 or Iowar. . . . . . . . . . . . . . . .

Great Ameriean. . . . . . . . . . . . . . . .

Big Four or Silvermine.................

Early Prolifio.

Special prices 100 bushels or over

\section{SPRING WHEAT}

Grood Heart Recleaned Seev

Illinois No. 1, high reeistance to seab ........

1 to 15 bushels................. \$1.95 per bu. 10 to 30 bushels..................\$1.90 per bu

35 bushels and up..............\$1.85 per bu. Marquis. Ask for prives

$+$

\section{BARLET}

Volvet Barbles. ......................

Wisconsin Pedigreed Ask for prices

\section{MASCELLANEOUS}

SUDAN GRASS............... 7 \& per pound

Red Top................... 20\& per pound

Orchard Grass................. 25\& per pound

Rapo, broad leaf Holland ........... of per pound

Timothy. . (21/2 bu. bags, 32c each) . .\$3.25 per busbel

Kentucky Blue Grass............ 35 per pound

Lawn Grass Mixture............. 35k per pound

Funks Mineral Mixture..........\$2.50 per cwt. SEED CORN NURBERS $\$ 1.25$ Each 


\section{Funk's Field and Road Drain}

(Patented)

\section{Quick Removal of Surface Water In Al1 Seasons}

This drain provides for the immediate removal of surface waters from fields and roads. For years it has demonstrated its efficiency on the Funk Farms in McLean County. Illinois.

The advantage of the Drain is that it diverts all surface water directly into the tile. It prevents the formation of mud holes in roads and puts the low places in the field in shape to be worked with the rest of the land. The surface drainage from early summer rains is quickly moved into the tile without the crop loss due to scalding and drowning out. The winter killing hazard in low places is lessened by the immediate removal of water from fall rains and melting snow. There is no delay in seeding or cultivation at any season and no necessity for mudding in the crop.

The Drain is connected directly with the tiling in any field or road by one man in an hour's time. It is adjustable to any depth tile and is easily readjusted after it is once set. Made of cast iron it lasts for 35 or 40 years. Patents cover non-clogging, non-freezing and other essential features.

Fuuk's Field and Road Drain pays for itself in one season by insuring crops on land that would otherwise be unproductive. It insures flushing of the tile and materially increases its capacity. Located behind a dam it has been effective in stopping soil erosion.

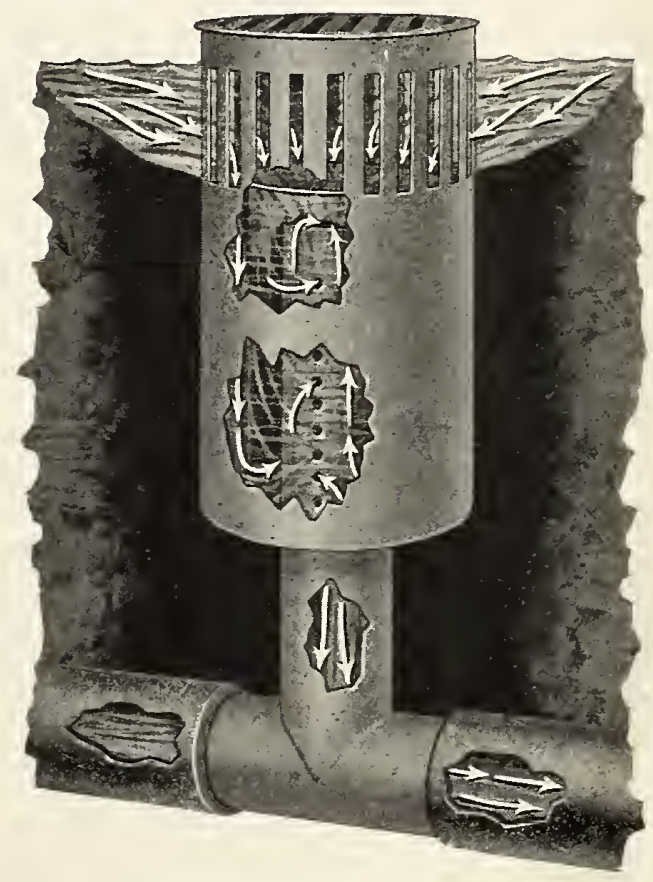

\section{Write for Prices and Literature}

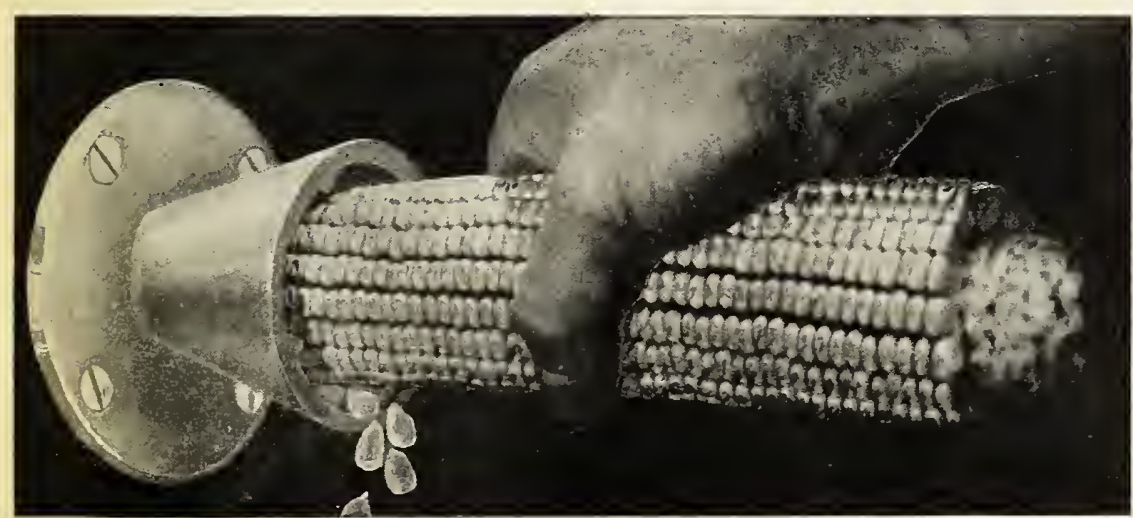

\section{Funk's Improved Nubber} $\$ 1.25$. E ach

\section{For Butting and Tipping the Ears}

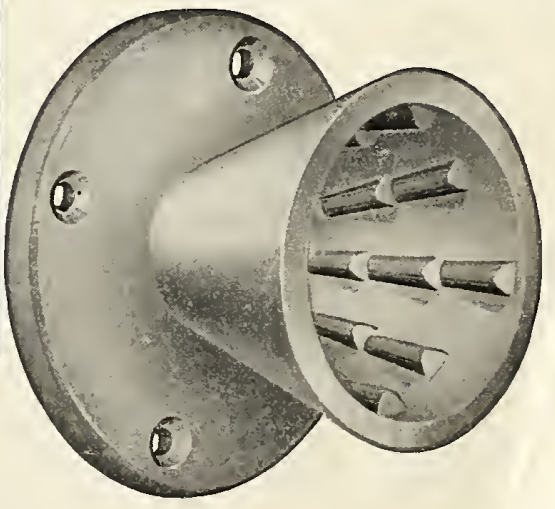




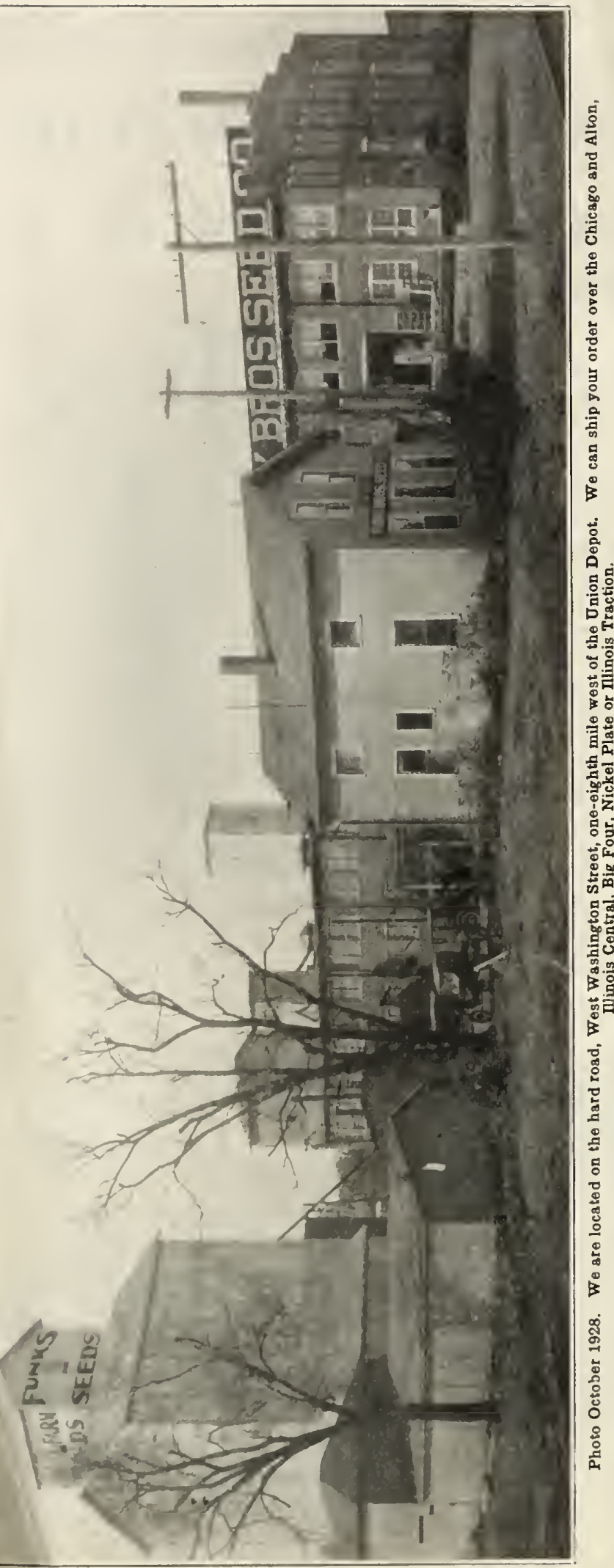

\section{Satisfaction Guaranteed}

FOUR STRAINS-ENOUGH TO PLANT ONE-

EIGHTH ACRE OF EACH. INCLUDES AT

LEAST TWO OF FUNKS FAMOUS HY-

BRIDS. \$2.00 FOR THE LOT POSTPAID.

CHECK WITH ORDER. YELLOW.

DISEASE FREE. TREATED.

Every farmer should place an order. Try out Funk's Famous Hybrid strains of corn. Plant them early, watch them grow. Cold resistance, vigor, high yields, combined with quality, have been bred into these new products of science. They are the latest word to date, quality and yield considered. We have unlimited faith in their performance if planted on land capable of producing corn at a profit. Which strain is best adapted to your farm can only be determined by test.

Place your order early-compare these strains with the other corn on your farm. Plant it where you can watch it grow, where your friends can see it, where the boys can see it from the time it peeps out of the ground until it is ready to harvest. Treat it right and if you tell us next fall it was not one of the most interesting experiments as well as one of the best investments you ever made your purchase price will be cheerfully refunded.

The Sample Package will contain at least two Hybrids selected to suit conditions in your locality. Satisfy yourself as to the superiority of IIybrid corn by growing it yourself. The cost is negligible. We have produced more of this corn this year than ever before. The demand has always exceeded the supply. Only a limited amount is available for use in the Sample Package.

Funk's originated the Utility Type corn so widely grown at the present time. There is no question as to the superiority of Utility Type Corn. Use these openpollinated varieties to put some new corn blood into your best cash crop.

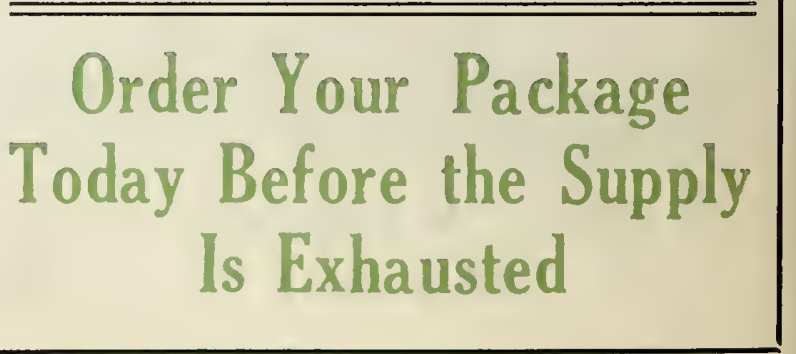

